\title{
Formation of seep carbonates along the makran convergent margin, northern Arabian sea and a molecular and isotopic approach to constrain the carbon isotopic composition of parent methane
}

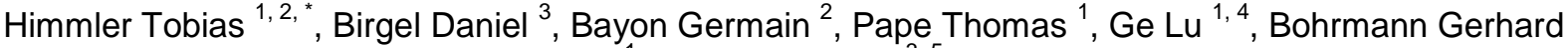 \\ ${ }^{1}$, Peckmann Jorn ${ }^{3,5}$
}

${ }^{1}$ MARUM - Center for Marine and Environmental Sciences and Department of Geosciences, University of Bremen, 28334 Bremen, Germany

2 IFREMER, Unité de Recherche Géosciences Marines, 29280 Plouzané, France

3 Institute of Geology, University of Hamburg, 20146 Hamburg, Germany

${ }^{4}$ State Key Laboratory for Mineral Deposits Research, Department of Earth Sciences, Nanjing

University, Nanjing 210093, China

${ }^{5}$ Department of Geodynamics and Sedimentology, Center for Earth Sciences, University of Vienna, 1090 Vienna, Austria

*Corresponding author : Tobias Himmler, email address : thimmler@uni-bremen.de

\begin{abstract}
:
Authigenic carbonate deposits have been sampled with the remotely operated vehicle 'MARUM-QUEST $4000 \mathrm{~m}$ ' from five methane seeps between 731 and $1823 \mathrm{~m}$ water depth along the convergent Makran continental margin, offshore Pakistan (northern Arabian Sea). Two seeps on the upper slope are located within the oxygen minimum zone (OMZ; ca. 100 to $1100 \mathrm{~m}$ water depth), the other sites are situated in oxygenated water below the OMZ (below $1100 \mathrm{~m}$ water depth). The carbonate deposits vary with regard to their spatial extent, sedimentary fabrics, and associated seep fauna: Within the OMZ, carbonates are spatially restricted and associated with microbial mats, whereas in the oxygenated zone below the OMZ extensive carbonate crusts are exposed on the seafloor with abundant metazoans (bathymodiolin mussels, tube worms, galatheid crabs). Aragonite and $\mathrm{Mg}$-calcite are the dominant carbonate minerals, forming common early diagenetic microcrystalline cement and clotted to radialfibrous cement. The $\delta 180$ carbonate values range from 1.3 to $4.2 \% \mathrm{~V}$-PDB, indicating carbonate precipitation at ambient bottom-water temperature in shallow sediment depth. Extremely low 13 Ccarbonate values (as low $-54.6 \%$ V-PDB) point to anaerobic oxidation of methane (AOM) as trigger for carbonate precipitation, with biogenic methane as dominant carbon source. Prevalence of biogenic methane in the seepage gas is corroborated by $\delta 13 \mathrm{Cmethane}$ values ranging from -70.3 to $66.7 \%$ V-PDB, and also by back-calculations considering $\delta 13 \mathrm{Cmethane}$ values of carbonate and incorporated lipid biomarkers. These calculations $(\Delta \delta 13 \mathrm{C}$ methane-carbonate, $\Delta \delta 13 \mathrm{CANME}-\mathrm{methane}$, $\triangle \delta 13 \mathrm{CMOX}$-methane) prove to be useful to assess the carbon stable isotope composition of seeping methane if this has not been determined in the first place; such an approach represents a useful tool to reconstruct fluid composition of ancient seeps. AOM is also revealed by lipid biomarkers of anaerobic
\end{abstract}


methane oxidizing archaea such as crocetane, pentamethylicosane (PMI), and sn2-hydroxyarchaeol strongly depleted in $13 \mathrm{C}$ ( $\delta 13 \mathrm{C}$ values as low as - $127 \%$ V-PDB). Biomarkers of sulphate-reducing bacteria are also abundant, showing slightly less negative $\delta 13 \mathrm{C}$ values, but still significantly $13 \mathrm{C}$ depleted (average values as low as - 101\%). Other bacterial biomarkers, such as bacteriohopanepolyols (BHPs), hopanols, and hopanoic acids are detected in most carbonates, but are particularly common in seep carbonates from the non-OMZ sites. The BHP patterns of these carbonates and their low $\delta 13 \mathrm{C}$ values resemble patterns of aerobic methanotrophic bacteria. In the shallower OMZ sites, BHPs revealed much lower contents and varying compositions, most likely reflecting other sources than aerobic methanotrophic bacteria. 230Th/U carbonate ages indicate that AOM-induced carbonate precipitation at the deeper non-OMZ seeps occurred mainly during the late PleistoceneHolocene transition, i.e. between 19 and 15 ka before present, when the global sea level was lower than today.

\section{Highlights}

- Seep carbonates were sampled across an oxygen minimum zone (OMZ). Sedimentary fabrics of seep carbonates vary across the OMZ. Lipid biomarkers indicate AOM induced carbonate formation. - Carbonates were formed mainly between 19 and 15 ka BP. Biomarkers of aerobic methanotrophs were preserved within carbonates. Carbon partitioning between methane, carbonate, and organic molecules reveals methane source.

Keywords : Anaerobic oxidation of methane, Authigenic carbonates, Cold-seep carbonates, makran subduction zone, Oxygen minimum zone, Methane, Lipid biomarkers

\section{Introduction}

Methane-enriched fluids emanate from the seabed into the water column at cold seeps along continental margins (e.g., Kulm et al., 1986, Judd and Hovland, 2009 and Suess, 2014). Seepage rates cover a broad range from slow diffusive to strong advective fluid flow (e.g., Tryon et al., 1999, Torres et al., 2002, Solomon et al., 2008 and Römer et al., 2012). Due to variable methane ascent in time, the redox conditions can vary significantly at individual methane seeps (e.g., Cai et al., 2006, Solomon et al., 2008, Feng et al., 2009, Feng et al., 2013 and Birgel et al., 2011). When the ascending methaneenriched fluids reach sulphate-rich pore water, the greater portion of methane is consumed by sulphatedependent anaerobic oxidation of methane (AOM; e.g., Barnes and Goldberg, 1976 and Hoehler et al., 1994):

$$
\mathrm{CH}_{4}+\mathrm{SO}_{4}{ }^{2-} \rightarrow \mathrm{HCO}_{3}{ }^{-}+\mathrm{HS}^{-}+\mathrm{H}_{2} \mathrm{O}(\mathrm{AOM})
$$

AOM is mediated by consortia of anaerobic methanotrophic archaea (ANME) and sulphate-reducing bacteria (SRB; Hoehler et al., 1994, Hinrichs et al., 1999, Boetius et al., 2000 and Milucka et al., 2012). Dependent on methane and sulphate concentrations, temperature, and oxygen availability, the phylogenetic composition of ANME/SRB consortia varies from site to site (e.g., Knittel et al., 2005, Nauhaus et al., 2005 and Rossel et al., 2011). AOM produces excess dissolved inorganic carbon (DIC), thus promoting carbonate supersaturation and 
precipitation of ${ }^{13} \mathrm{C}$-depleted authigenic carbonate (Berner, 1980; Ritger et al., 1987; Paull et al., 1992; Aloisi et al., 2002; Luff et al., 2004; Peckmann and Thiel, 2004; Ussler and Paull, 2008; Suess, 2014). The timing of past seepage activity as well as successive environmental change can be reconstructed by examining the ${ }^{230} \mathrm{Th} / \mathrm{U}$ ages of authigenic cold-seep carbonates (e.g., Teichert et al., 2003; Feng et al., 2010; Bayon et al., 2013; Crémière et al., 2013; Han et al., 2014). Seep carbonates constitute valuable geochemical archives that record the chemical composition of the seepage fluid (e.g., Teichert et al., 2003; Formolo et al., 2004; Naehr et al., 2007). Moreover, the presence of molecular fossils preserved in seep carbonates and the relative abundance of early diagenetic cement allow to discriminate between diffusive and advective methane flux (e.g., Peckmann et al., 2009; Haas et al. 2010; Birgel et al., 2011; Natalicchio et al., 2015). The dimensions of seep deposits range from mmsized concretions over m-wide crusts to seafloor build-ups hundreds of meters in diameter (e.g., Ritger et al., 1987; Paull et al., 1992; Roberts and Aharon, 1994; Greinert et al., 2001; Teichert et al., 2005; Reitner et al., 2005; Ussler and Paull, 2008; Roberts et al., 2010; Römer et al., 2014).

Methane seeps have been discovered on the Makran continental margin, offshore Pakistan (von Rad et al., 1996, 2000). Systematic investigations during R/V METEOR expedition M74 (Legs 2 and 3) in 2007 gathered ample new information on these seeps (e.g., Ding et al., 2010; Himmler et al., 2010; Fischer et al., 2012, 2013; Römer et al., 2012; Yoshinaga et al., 2012). More than a dozen seafloor gas emission sites, named 'Flare' sites, have been documented (Römer et al., 2012). Detailed seafloor investigation with a remotely operated vehicle (ROV) revealed the widespread occurrence of chemosynthesis-based communities and seep carbonate deposits.

Compared to the structural setting (von Rad et al., 2000; Ding et al., 2010; Smith et al., 2014) and local seep biogeochemistry (Schmaljohann et al., 2001; Fischer et al., 2012; 2013; 
Römer et al., 2012; Yoshinaga et al., 2012), only little is known about the Makran continental margin seep carbonates (von Rad et al., 1996; Himmler et al., 2010). This study describes five newly discovered seep deposits from Flare sites along the upper and middle slope of the Makran continental margin. Almost all investigated seeps showed gas bubble emission and seep-dwelling organisms at the time of exploration. The examined data are used to assess the geochemical environment and timing of seep carbonate precipitation. This study sheds new light on seep carbonate authigenesis under different bottom water oxygen concentrations. The variable settings on the Makran continental margin with their different redox conditions allow us to assess the dependence of the microbial populations on the chemical environment, a pattern that is also reflected in different modes of mineral formation. Finally, the presence of different groups of methane-consuming prokaryotes in this range of environments enabled us to refine the molecular and isotopic proxies to reconstruct the carbon isotopic composition of parent methane from seep carbonates.

\section{Geological setting and hydrography}

Convergence between the Arabian and the Eurasian plates since the Late Cretaceous and deposition of erosional material from the mounting Himalayan range gave rise to a ca. $7 \mathrm{~km}$ thick accretionary prism, today comprising the Makran coastal regions of southern Iran and Pakistan (Farhoudi and Karig, 1977; White, 1984; Kopp et al., 2000; Golonka, 2004). The Makran continental margin, constituting the submerged part of the Makran accretionary prism, structurally forms an extensive imbricate thrust belt (Kopp et al., 2000; Kukowski et al., 2001). The uppermost subducted sediments form abundant anticlinal hinges where shallow gas accumulates and migrates along normal faults to seep at the seafloor (Ding et al., 2010; Römer et al., 2012; Smith et al., 2014). Seismic studies revealed a bottom simulating 
reflector (BSR) at about 500 to $800 \mathrm{~m}$ below seabed across the Makran continental margin, indicating widespread occurrence of gas hydrates and free gas below the BSR (e.g., White, 1984; Sain et al., 2000). The water temperature, salinity, and gas molecular composition sets the upper boundary of the gas hydrate stability zone at approximately $850 \mathrm{~m}$ water depth (Bohrmann et al., 2008).

Due to intense water column oxygen respiration resulting from high primary production acting in concert with a high particle flux and low thermocline ventilation, a pronounced water column oxygen minimum zone (OMZ; oxygen concentrations $<0.05 \mathrm{ml} / \mathrm{l})$ persists in the northern Arabian Sea (Wyrtki, 1973; Qasim, 1982; Olson et al., 1993; Reichart et al., 1998). The OMZ seawater inundates the upper slope of the Makran continental margin between ca. 100 and 1100 mbsl (meters below sea level; Fig. 1), including methane seeps (von Rad et al., 2000; Fischer et al., 2012; Römer et al., 2012).

\section{Material and methods}

Carbonate rocks were sampled from seafloor deposits using the manipulator arm of the ROV MARUM-QUEST 4000 m during R/V METEOR expedition M74/3 in 2007 (Fig. 2; Table 1). The bottom water temperature was measured with the ROV-mounted temperature sensor and seafloor photographs were captured with digital cameras. The rock samples were cut in slabs from which thin sections $(100 \times 150 \mathrm{~mm})$ were prepared for standard petrographic and fluorescence microscopy on a Zeiss Axioskop 40A microscope. The carbonate content $\left(\mathrm{CaCO}_{3}\right.$ weight-\%) was determined on bulk-rock powders using the 'Karbonat-Bombe' device (absolute error $\pm 1 \%$; Müller and Gastner, 1971). Semi-quantitative X-ray diffraction (XRD) analyses were performed on powdered rock fragments or powders obtained with a 
handheld micro drill from the slabs, using a Phillips X'Pert Pro MD X-ray diffractometer equipped with a $\mathrm{Cu}-\mathrm{K}_{\alpha}$-tube $(\lambda=1.541 ; 45 \mathrm{kV}, 40 \mathrm{~mA})$.

Carbonate carbon and oxygen stable isotopes were analysed on powders obtained from the cut slabs with a handheld micro drill. The powder was reacted with $100 \%$ phosphoric acid at $75^{\circ} \mathrm{C}$ and the released carbon dioxide was injected into a Finigan MAT 251 mass spectrometer. Carbonate $\delta^{13} \mathrm{C}$ and $\delta^{18} \mathrm{O}$ values are reported in per mill (\%o) relative to the Vienna-Pee Dee Belemnite (V-PDB) standard. Reproducibility was checked by replicates of an internal standard (Solnhofen limestone) calibrated against the NBS19 standard. Long term standard deviation for carbonate $\delta^{13} \mathrm{C}$ and $\delta^{18} \mathrm{O}$ analyses is less than $0.05 \%$ o $\left(\delta^{13} \mathrm{C}\right)$ and $0.07 \%$ $\left(\delta^{18} \mathrm{O}\right)$

Uranium (U) and thorium (Th) concentrations and isotopic ratios were determined as described by Bayon et al. (2009). Between 11 and $15 \mathrm{mg}$ of rock powder was transferred into a TEFLON® vial before adding $200 \mu$ l of a mixed ${ }^{236} \mathrm{U} /{ }^{229} \mathrm{Th}$ spike. The samples were digested on a hot plate using nitro-hydrochloric acid (aqua regia), and, if required, any residue was digested using a mixed hydrochloric-hydrofluoric acid. Dissolved U and Th were pre-concentrated using Fe-oxyhydroxide co-precipitation. Uranium and Th were isolated by ion exchange chromatography (following a procedure adapted from Edwards et al. (1986), and analysed with a Neptune multi collector-inductively coupled plasma-mass spectrometer (MC-ICP-MS). Measured isotopic ratios were corrected for mass discrimination by standard bracketing, using IRMM-184 (U) and IRMM-035 (Th) standard solutions. The precision obtained on ${ }^{238} \mathrm{U} /{ }^{234} \mathrm{U}$ and ${ }^{229} \mathrm{Th} /{ }^{230} \mathrm{Th}$ ratios were generally better than $50 \%$ and $5 \%$, respectively. Carbonate ages were corrected for detrital contamination using an isochron approach, considering a sediment end-member assumed to be at secular equilibrium (i.e. activity ratios $=1.0 \pm 0.5$ ). Isochron ages were calculated from measured activity ratios of 
$\left({ }^{232} \mathrm{Th} /{ }^{238} \mathrm{U}\right),\left({ }^{230} \mathrm{Th} /{ }^{238} \mathrm{U}\right)$, and $\left({ }^{234} \mathrm{U} /{ }^{238} \mathrm{U}\right)$, using the ISOPLOT freeware (v.3.71; Ludwig, 2009), and the nuclide half-lives $\left({ }^{238} \mathrm{U},{ }^{234} \mathrm{U},{ }^{232} \mathrm{Th},{ }^{230} \mathrm{Th}\right.$ ) of Cheng et al. (2000).

The extraction procedure of carbonate associated lipid biomarkers followed the protocols of Thiel et al. (1999) and Birgel et al. (2006). The carbonates were crushed and fragments (smaller than $1 \mathrm{~cm}$ in diameter) were placed in deionized water and decalcified by slowly adding $10 \%$ hydrochloric acid until $\sim 80 \%$ of the carbonate matrix was dissolved. The organic residue was extracted with 3:1 (vol:vol) dichloromethane (DCM):methanol in an ultrasonic bath yielding the total lipid extract (TLE). An aliquot of the TLE was separated by column chromatography into hydrocarbons, alcohols, and fatty acids (see Birgel et al., 2008 for details). The alcohols were derivatized by adding $100 \mu \mathrm{l}$ pyridine and $100 \mu \mathrm{l}$ N,O-bis(trimethylsilyl)-trifluoracetamide (BSTFA) at $70^{\circ} \mathrm{C}$ for $30 \mathrm{~min}$. Fatty acids were reacted with $1 \mathrm{ml} 14 \%$ boron trifluoride in methanol at $70^{\circ} \mathrm{C}$ for $1 \mathrm{~h}$ to form fatty acid methyl esters. After cooling, the mixture was extracted four times with $n$-hexane. The obtained fractions were analysed using coupled gas chromatography-mass spectrometry (GC-MS) with an Agilent 7890 A GC system coupled to an Agilent 5975C inert MSD mass spectrometer.

Quantification was done using GC-flame ionization detection (GC-FID) with an Agilent 7820 A GC system. Both GC systems were equipped with a HP-5 MS UI fused silica column (30 m x $0.25 \mathrm{~mm}$ i.d., $0.25 \mu \mathrm{m}$ film thickness). The carrier gas was helium. The GC temperature program for all fractions was: $60^{\circ} \mathrm{C}(1 \mathrm{~min})$ to $150^{\circ} \mathrm{C}$ at $10^{\circ} \mathrm{C} / \mathrm{min}$, then to $320^{\circ} \mathrm{C}$ (held 25 min) at $4^{\circ} \mathrm{C} / \mathrm{min}$. Compound assignments were based on retention times and published MS data.

For bacteriohopanepolyol (BHP) analysis, another aliquot of the TLE was separated over a tightly packed glass wool Pasteur pipette into an $n$-hexane soluble phase and a DCM soluble phase. The separation of the total lipid extract into two fractions for BHP analysis was chosen to exclude other hopanoids (diplopterol, diploptene, hopanols, hopanoic acids) in the extract. 
The DCM fraction was then acetylated using acetic anhydride in pyridine (1:1) at $50^{\circ} \mathrm{C}$ for 1 h. Then, the mixture was left to stand overnight. BHPs were analysed via atmospheric pressure chemical ionization-liquid chromatography/multi stage ion trap mass spectrometry $\left(\mathrm{APCI}-\mathrm{LC} / \mathrm{MS}^{\mathrm{n}}\right.$ ) on a Thermo Finnigan LCQ Deca XP Plus ion trap mass spectrometer in data dependent mode with fragmentation up to $\mathrm{MS}^{3}$ (modified after Talbot et al., 2003). Briefly, an Agilent 1200 series high performance liquid chromatography (HPLC) system consisting of autosampler, binary pump, and column oven equipped with a reversed phase column (Alltech Prevail C18, 150 x $2.1 \mathrm{~mm}, 3 \mu \mathrm{m}$; Alltech, Munich, Germany) and a guard column of the same packing material $(7.5 \times 2.1 \mathrm{~mm})$, was heated to $30^{\circ} \mathrm{C}$. Prior to injection, the acetylated fraction of the TLE was dissolved in $10 \mu \mathrm{l}$ of methanol/propan-2-ol (60:40 v/v). The separation was achieved by using the following gradient: hold $0 \% \mathrm{~B}$ for $3 \mathrm{~min}$, then ramp to $100 \% \mathrm{~B}$ at $25 \mathrm{~min}$, hold $100 \% \mathrm{~B}$ to $30 \mathrm{~min}$ with $\mathrm{A}=$ methanol:deionized water $(90: 10 \mathrm{v} / \mathrm{v})$ and $\mathrm{B}=$ methanol:deionized water:propan-2-ol (54:1:45). The flow rate of the eluents was set to $0.2 \mathrm{ml} / \mathrm{min}$. The APCI source was operated in positive ionization mode with vaporizer temperature of $400^{\circ} \mathrm{C}, 5 \mu \mathrm{A}$ discharge current and sheath gas flow 20 (arbitrary unit). To measure stable carbon isotopes of BHPs, the acetylated dichloromethane fractions already measured on the HPLC-MS were first deacetylated according to Neunlist et al. (1985). To deprotect the acetylated aminotetrol and aminotriol, $25 \mathrm{mg}$ of the resin Amberlist A-26 were used and the extract was dissolved in $1 \mathrm{ml}$ methanol and tetrahydrofuran $(1: 1 \mathrm{v} / \mathrm{v})$. Subsequently the mixture was stirred at room temperature for $1 \mathrm{~h}$ and later filtered into a Pasteur pipette with a glass wool plug. As a note of caution, this procedure only deprotects the hydroxyl $(-\mathrm{OH})$ functional group, but not the amine group of aminotriol and aminotetrol. However, the emphasis was put on the cleavage of the vicinal alcohols with the periodic acid cleavage procedure by Rohmer et al. (1984), where all functional groups are cleaved of except for the vicinal hydroxyl group. The cleavage of BHPs was done with periodic acid, the 
resulting hopanones were reduced to GC-amenable hopanols with sodium boron hydride. Finally, the hopanols were derivatized with BSTFA and pyridine as described above for the alcohols. This two-step deprotection-cleavage procedure was used to measure carbon isotope compositions on the same samples which were run beforehand on the HPLC-MS, without any contamination of low molecular weight hopanoids (i.e. diplopterol, hopanols, hopanoic acids). Compound-specific carbon isotope compositions of all GC fractions and deprotected and periodic acid cleaved BHPs were measured with a Thermo Fisher Trace GC Ultra connected via a Thermo Fisher GC Isolink interface to a Thermo Fisher Delta V Advantage spectrometer. Compound-specific carbon isotope values are given as $\delta^{13} \mathrm{C}$ values in per mill (\%) relative to V-PDB. The $\delta^{13} \mathrm{C}$ values of alcohols and cleaved BHP-derived hopanols (TMS derivatives) and fatty acids (methyl esters) were corrected for the additional carbons introduced after derivatization. The GC conditions were identical to those described above. Each measurement was calibrated using several carbon dioxide gas pulses of known $\delta^{13} \mathrm{C}$ composition prior and after the run. Precision was checked with an $n$-alkane mixture $\left(\mathrm{C}_{14}\right.$ to $\mathrm{C}_{38}$ ), also of known isotopic composition. Analytical standard deviation was below $0.7 \%$.

Gas bubbles released from the seafloor at Flare sites 15 and 7 were sampled with the Gas Bubble Sampler (GBS; Pape et al., 2010) during ROV dives 196, 182, and 191. After recovery on deck, the gas was stepwise released from the GBS pressure chamber into a gastight syringe and injected into glass vials for storage until analysis (see Pape et al., 2010). Stable carbon isotopic signatures of methane in the sampled gas were determined using a Trace GC Ultra connected via a GC IsoLink and ConFlo IV interface to a MAT 253 isotope mass spectrometer (Römer et al., 2012). Duplicates of at least two subsamples of the entire gas collected during a single GBS deployment were examined for calculation of mean $\delta^{13} \mathrm{C}_{\text {methane }}$ values; the reproducibility is estimated at $\pm 0.2 \%$. The $\delta^{13} \mathrm{C}_{\text {methane values are }}$ reported in per mill (\%o) relative to the V-PDB standard. 


\section{Results}

\subsection{Visual seafloor observations}

\subsubsection{OMZ seeps (Flare sites 15 and 2)}

The shallowest sample investigated in this study was recovered from Flare site 15, located within the OMZ on the upper slope at $731 \mathrm{~m}$ mbsl (Fig. 1; Table 1). The area comprised a smooth seafloor of olive to brownish sediment, covered with scattered patches of white and orange concentric microbial mats (Fig. 2A). The orange mats were generally encircled by white mats. During ROV dive 196 gas bubbles emanated frequently through the mats. On the seabed between the microbial mats no macrobenthos and bioturbation traces were discernible. Some of the patches showed a convex morphology, generally not exceeding $30 \mathrm{~cm}$ above the seafloor (Fig. 2A). The sediment underneath the microbial mat was black coloured (Fig. 2A). A columnar carbonate of $\sim 20 \mathrm{~cm}$ diameter projecting $\sim 50 \mathrm{~cm}$ above the seafloor was discovered nearby the microbial patches, however, without a microbial mat cover.

Flare 2 rose from about $1025 \mathrm{mbsl}$ at the lower boundary of the OMZ (Fig. 1; Table 1). During ROV dive 181 gas bubbles emanated from an elongated seafloor depression. The seafloor at the central part of the depression was distorted by cracks and fissures and vastly covered by irregular patches of white and orange microbial mats. The mats were bordered by ampharetid polychaetes and surrounded by colonies of vesicomyid clams. At the margin of the elongated depression broken slabs of a centimetre-thin crust were exposed and sampled (Fig 2B).

\subsubsection{Non-OMZ seeps (Flare sites 11, 7, and 6)}


Flare 11 was detected above a steep crest, placed on the middle slope at about $1475 \mathrm{mbsl}$ (Fig. 1, Table 1). ROV dive 194 revealed widespread carbonate crusts settled by superabundant bathymodiolin mussels (Fig. 2C). Among and over the mussels numerous white galatheid crabs strolled (Fig. 2C). The crabs occurred in such high density that the mussels and carbonates below them were almost completely disguised. Adjacent to the carbonate deposit vesicomyid clams dwelled in soft sediment.

Flare site 7 was situated at the top of a $\sim 30 \mathrm{~m}$ high elevation on the middle slope at about 1656 mbsl (Fig. 1). On the mound-top carbonate crusts were exposed on the seabed. Abundant dead clams as well as a single tube worm bush were observed during ROV dive 194 (Fig. 2D; Table 1). Nearby the outcrop on the mound top, an extensive carbonate crust was found settled by numerous bathymodiolin mussels, whitish sponges, galatheid crabs, and deep sea barnacles (Fig. 2E). In the soft sediment nearby the crust several clusters of vesicomyid clams were observed. A vast portion of the carbonate crust was covered by hemipeleagic sediment and accumulations of disarticulated bivalve shells.

Flare site 6 represented the deepest site sampled in this study (1823 mbsl). This site was located at the transition from a mid-slope terrace to the lower slope (Fig.1). Extensive carbonate crusts were observed on the seafloor during ROV dive 186. Whitish sponges and colonies of living tube worms as well as bathymodiolin mussels were attached to the exposed carbonate crust (Fig. 2 F).

\subsection{Mineralogy and petrography}

\subsubsection{OMZ samples (Flare sites 15 and 2)}

Sample GeoB12353-7 was recovered from Flare site 15 underneath a microbial mat, composed almost exclusively of aragonite (99 wt-\% carbonate content), which forms clotted 
microcrystalline aggregates enclosed by clear radial-fibrous cement (Table 2; Figs. 3A, 4A). The sample shows a layered fabric of friable dark grey and well cemented light brownish layers (Fig. 3A). Large pores of $0.5 \mathrm{~mm}$ to $0.5 \mathrm{~cm}$ in diameter connect the layers (Fig. 3A). Under ultra-violet light the clotted aggregates exhibit intense fluorescence, whereas clear radial-fibrous crystals are non-luminescent (Fig. 4 B). Only few bioclasts (e.g., planktic foraminifera, pteropods) were spotted in thin sections.

A cm-thin layer of carbonate cemented sediment was sampled at Flare 2 (Fig. 2B; GeoB12315-3). The sample contains $65 \mathrm{wt}-\%$ carbonate of mainly microcrystalline aragonite and traces of calcite and dolomite (Table 2). Microcrystalline aragonite cemented a homogenous matrix of hemipelagic sediment comprising silt-sized quartz, feldspars, and few foraminifera tests (Fig. 4C).

\subsubsection{Samples from non-OMZ seeps (Flare sites 11, 7, and 6)}

Sample GeoB12348-1, retrieved from Flare site 11, comprises 90 wt- $\% \mathrm{CaCO}_{3}$ of mainly aragonitic mineralogy with traces of calcite and dolomite (Table 2). Major non-carbonate components are mica, quartz, feldspar, and chlorite. Nodular millimetre-sized sediment clasts are loosely packed and cemented by radial-fibrous and clotted cement, exhibiting a porous brecciated fabric (Figs. 3C, 4D). Within a large pore a juvenile bathymodiolin bivalve is attached to the surface (Fig. 3C). The intraclast nodules are composed of carbonate-cemented sediment containing abundant silt-sized quartz grains, fragments of bivalve shells, and planktic foraminifers (Fig. 4D). Bioturbation traces are common in the clast matrix.

Two carbonate specimens were sampled at Flare site 7 (samples GeoB12338-2 and GeoB12338-13; Figs. 3D, E). GeoB12338-2 contains mainly aragonite (carbonate content = $81 \mathrm{wt}-\%)$ in form of microcrystalline and botryoidal cement, with mainly quartz and minor feldspar and clay minerals as non-carbonate components (Himmler et al., 2010). The sample 
GeoB12338-13 contains abundant bivalve shells fragments and cemented sediment clasts.

The clasts comprise Mg-calcite cemented hemipelagic sediment of clay minerals with minor aragonite, quartz, and feldspar. Sediment clasts and shell fragments are cemented by isopachous radial-fibrous and clotted cement (Table 2; Fig. 3D). Articulated bathymodiolin mussels were cemented in situ, showing a thin layer of radial-fibrous cement coating the shell interior (Fig. 3D). Bioturbation traces are common in the clast matrix and in between the clasts. Peloids are observed cemented together with bivalve shell fragments and sediment clasts (Fig. 4E).

Authigenic carbonate sampled at Flare site 6 contains 80 wt- $\%$ of mainly aragonite with traces of calcite (GeoB12324-2; Table 2). Non-carbonate minerals include mica, feldspar, quartz, and chlorite. The sample exhibits a brecciated fabric of cemented angular to subrounded sediment clasts (Fig. 3F). Abundant silt-sized quartz grains, finely dispersed pyrite framboids, and few glauconite grains are observed in the strongly bioturbated clast matrix. The sediment clasts are cemented by radial-fibrous cement and remaining open pore space is partly filled by semi-lithified sediment (Fig. 4F). Large bivalve shell fragments and planktic foraminifers are common in the sediment matrix.

\subsection{Carbonate $\delta^{13} C$ and $\delta^{18} O$ values}

All samples exhibit negative $\delta^{13} \mathrm{C}$ values and positive $\delta^{18} \mathrm{O}$ values (Fig. 5). Samples from the OMZ show a slightly narrower range of $\delta^{13} \mathrm{C}$ values $(-54.3$ to $-48.8 \%$ ) than carbonates from the non-OMZ seeps (-54.6 to $-39.8 \%$ ). Similarly, the $\delta^{18} \mathrm{O}$ values of OMZ samples are slightly lower (1.3 to $2.1 \%$ ) than those of the deeper water samples (2.2 to $4.2 \%$ ).

Microcrystalline cement is less ${ }^{13} \mathrm{C}$-depleted and shows slightly lower $\delta^{18} \mathrm{O}$ values than the radial-fibrous and clotted cement (Fig. 5). 


\subsection{U-Th data and carbonate ages}

The ${ }^{238} \mathrm{U},{ }^{232} \mathrm{Th}$, and ${ }^{230} \mathrm{Th}$ contents range from 2 to $8 \mu \mathrm{g} / \mathrm{g}, 18$ to $4600 \mathrm{ng} / \mathrm{g}$, and 10 to 37 $\mathrm{pg} / \mathrm{g}$, respectively (Table 3). Overall, there is a tendency towards increasing U concentrations with water depth, from about $2.2 \mathrm{ppm}$ in the sample from the Flare site $2(1025 \mathrm{mbsl})$ to about 7.8 ppm at Flare sites 6 and 7 (1656 and 1823 mbsl, respectively). Bulk-rock powders yielded significantly higher ${ }^{232} \mathrm{Th}$ contents $(1900$ to $4600 \mathrm{ng} / \mathrm{g})$ than aragonite cement $(18 \mathrm{ng} / \mathrm{g})$. Likewise, ${ }^{230} \mathrm{Th}$ was lowest $(10 \mathrm{pg} / \mathrm{g})$ in aragonite cement, whereas bulk-rock powders yielded higher contents (14 to $37 \mathrm{pg} / \mathrm{g})$. Activity ratios determined for $\left({ }^{230} \mathrm{Th} /{ }^{232} \mathrm{Th}\right),\left({ }^{238} \mathrm{U} /{ }^{232} \mathrm{Th}\right)$, $\left({ }^{234} \mathrm{U} /{ }^{238} \mathrm{U}\right)$, ranged from 0.7 to $143,1.5$ to 936 , and 1.083 to 1.142 , respectively (Table 3$)$, yielding isochron carbonate ages between $0.01 \pm 32$ and $19.8 \pm 5$ thousand years before present (ka BP). Isochron-corrected initial $\delta^{234} U_{(i)}$ values for samples from Flare sites 7 and 6 range between 137 to $142 \%$, hence near the modern seawater value of $\delta^{234} U=146.6 \pm 2.5 \%$ o (Robinson et al., 2004). In contrast, samples from the two shallower sites (Flare sites 2 and 11) display markedly lower initial $\delta^{234} U_{i}$ values (83 and $123 \%$, respectively). Due to the low $\delta^{234} U_{i}$ and the large error, the calculated age of sample GeoB12315-3 is doubtful. The significant deviation of the $\delta^{234} \mathrm{U}_{\mathrm{i}}$ from the seawater value indicates that the calculated isochron age for sample GeoB12348-1 from Flare site $11(2.3 \pm 3.8 \mathrm{kyr}$ BP) should be used with caution.

\subsection{Lipid biomarker inventory and compound specific $\delta^{13} C$ values}

\subsubsection{Lipid biomarker patterns}


The lipids retrieved from the carbonate samples are mainly composed of bacterial-derived compounds (chiefly fatty acids and hopanoids) and archaeal-derived isoprenoid ethers and hydrocarbons (Table 4; Fig. 6). The total contents of the OMZ samples was $25218 \mu \mathrm{g} / \mathrm{g}$ rock (GeoB12353-7) and $3082 \mu \mathrm{g} / \mathrm{g}$ rock (GeoB12315-3); the three non-OMZ samples yielded $6464 \mu \mathrm{g} / \mathrm{g}$ rock (GeoB12348-1), $3206 \mu \mathrm{g} / \mathrm{g}$ rock (GeoB12324-2), and $1375 \mu \mathrm{g} / \mathrm{g}$ rock (GeoB12338-2).

Overall, bacterial lipids are more abundant in OMZ carbonates and comprise $84 \%$ and $78 \%$ of all compounds analysed at Flare sites 15 and 2, respectively (Fig. 6). In the non-OMZ carbonates, archaeal lipids are dominant with $64 \%$ of all lipids shown (Flare site 11) or are more or less equally distributed relative to bacterial fatty acids (e.g., Flare site 6). Flare site 7 is the only non-OMZ site with bacterial lipids predominating. The overall composition of the bacterial compounds, though, deviates from those in the carbonates from the OMZ. In the latter, fatty acids predominate ( 81 and $66 \%$ of all lipids for Flare sites 15 and 2, respectively), while they are only minor constituents in the non-OMZ samples (10\% in average) and bacterial-derived hopanoids are much more abundant, with highest contents found in the sample from Flare 7 (63\% of all compounds excluding BHPs; see also below; Fig. 6).

Among the aliphatic bacterial lipid biomarkers (fatty acids, monoalkyl glycerol monoethers (MAGEs), and dialkyl glycerol diethers (DAGEs)), anteiso- $\mathrm{C}_{15}$ fatty acid is the most abundant compound at all sites with the exception of Flare 15 , where $i s o-\mathrm{C}_{15}$ fatty acid is more prominent. MAGEs and DAGEs are only subordinate compared to fatty acids (Table 4). Among the hopanoids, $17 \beta(\mathrm{H}), 21 \beta(\mathrm{H})$-32-hopanoic acid is the most prominent hopanoid, whereas among the archaeal-derived isoprenoids, it is sn2-hydroxyarchaeol. Only in the sample from Flare 2, archaeol and the isoprenoid hydrocarbons crocetane, PMI and PMI $\Delta$ (sum of unsaturated PMIs) are equally abundant. 
Because no standards were available for BHPs at the time when the samples were measured, only relative intensities are displayed for the most prominent peaks (Fig. 7). The carbonates from the non-OMZ sites contain higher amounts of BHPs, in particular aminotetrol accompanied by minor amounts of aminotriol. In contrast, BHPs are much less abundant in the OMZ samples. In the Flare site 15 carbonate, no aminotetrol was detected but aminotriol and bacteriohopanetetrol (BHT). The Flare site 2 sample yielded aminotriol and aminotetrol with equal peak sizes, whereas the BHT peak was significantly smaller.

\subsubsection{Compound-specific $\delta^{13} C$ values}

Most lipid biomarkers show significant ${ }^{13} \mathrm{C}$-depletion, with the isoprenoids yielding the lowest $\delta^{13} \mathrm{C}$ values (Table 4). Although the contents of the archaeal-derived isoprenoids vary between sites, the $\delta^{13} \mathrm{C}$ values are similarly negative ( -127 to $-106 \%$ ); only crocetane is slightly less ${ }^{13} \mathrm{C}$-depleted at Flare sites 2 and 11 ( -85 and $-78 \%$, respectively). Possibly other, so far unknown archaea thriving at these seep sites produce crocetane as well. Since no signifant contributions of phytane were detected in any of the samples, a co-elution with crocetane can be excluded as the reason for the deviant isotope signatures. The ${ }^{13} \mathrm{C}$-depleted bacterial-derived aliphatic biomarkers show somewhat stronger variations, ranging from -112 to $-85 \%$. The terminally-branched fatty acids $i$ - and $a i-\mathrm{C}_{15}$ fatty acid yielded values ranging from -107 to $-85 \%$. The hopanoids (also including compounds resulting from periodic-acid cleavage of BHPs) showed $\delta^{13} \mathrm{C}$ values, ranging from $-84 \%$ for $17 \beta(\mathrm{H}), 21 \beta(\mathrm{H})$-32-hopanoic acid (Flare site 11 ) to -48 and $-41 \%$ for $17 \beta(\mathrm{H}), 21 \beta(\mathrm{H})-32$-hopanoic acid at OMZ Flare sites 15 and 2, respectively (Table 5). Periodic acid cleavage derived 17ß(H),21ß(H)-31-hopanol (from aminotetrol) varying from $-78 \%$ at Flare 11 to $-73 \%$ at Flare 7 . The majority of $\delta^{13} \mathrm{C}$ 
values of hopanoids, though, varies only from -84 to $-70 \%$ (Table 5). The lower values are recorded exclusively in non-OMZ samples.

$4.6 \delta^{13} C$ values of methane in seeping gas

Average $\delta^{13} \mathrm{C}$ values of methane in gas escaping the seafloor measured in this study are $-70.3 \%$ (Flare site 15 ) and $-66.7 \%$ (Flare site 7 ). The $\delta^{13} \mathrm{C}$ value of gas from Flare site 2 $(-68.5 \%)$ is adopted for discussion from Römer et al. (2012).

\section{Discussion}

\subsection{Implications on the carbonate formation environment}

\subsubsection{Timing of AOM-induced carbonate formation}

The strong ${ }^{13} \mathrm{C}$-depletion of the Makran continental margin carbonates clearly points to AOM-induced precipitation at all sampling sites within and below the OMZ. The slightly less negative $\delta^{13} \mathrm{C}$ values of microcrystalline cement likely result from the admixture of relatively ${ }^{13} \mathrm{C}$-rich bioclasts (mostly planktic foraminifers) or precipitation of microcrystalline carbonate phases during periods of less vigorous seepage (e.g., Luff and Wallmann, 2003; Peckmann et al., 2009). A causal link between AOM and carbonate authigenesis is also confirmed by

carbonate-associated ${ }^{13} \mathrm{C}$-depleted lipid biomarkers, comprising compounds such as archaeol, PMI, and anteiso- $\mathrm{C}_{15}$ fatty acid (e.g., Thiel et al., 1999, 2001; Pape et al., 2005; Stadnitskaia et al., 2008; Haas et al., 2010; Birgel et al., 2011).

The ROV-surveys revealed that the local spatial extent of carbonates on the seabed is lower within the OMZ, compared to the large carbonate deposits of the non-OMZ seeps. The 
timing of AOM-induced carbonate precipitation can be deduced from ${ }^{230} \mathrm{Th} / \mathrm{U}$ analyses (e.g., Teichert et al., 2003; Bayon et al., 2009, 2013; Feng et al., 2010; Crémière et al., 2013; Han et al., 2014). Most of the calculated ${ }^{230} \mathrm{Th} / \mathrm{U}$ carbonate ages for the Makran seeps have large errors (Table 3) and are thus deemed doubtful. The bulk-rock nature of most samples results in relatively high ${ }^{230} \mathrm{Th}$ and ${ }^{232} \mathrm{Th}$ contents, which are probably to a large extent inherited from detrital clay minerals rather than decay of seawater-derived ${ }^{234} \mathrm{U}$ ingrown into the carbonate (e.g., Bayon et al., 2009). However, the measured U and Th contents are within the range of cold-seep carbonates (e.g., Teichert et al., 2003; Bayon et al., 2009; Feng et al., 2010; Crémière et al., 2013; Han et al., 2014). In particular, the ages obtained from carbonates sampled from Flare sites 2 and 11 are ambiguous. Lithification of the $\mathrm{cm}$-thin layer at Flare site 2 probably occurred during a relatively short time interval, presumably within several hundreds of years (cf. Luff et al., 2004; Bayon et al., 2009), although the absolute age remains unclear. It is assumed that this sample is indeed much younger than the decimetre-thick deposits at the deeper non-OMZ seeps. Similarly, despite the large uncertainty associated with the isochron age determined for the Flare site 11 sample $(2.3 \pm 3.8 \mathrm{ka} \mathrm{BP})$, it is likely that carbonate precipitation has occurred relatively recently.

The most accurate ${ }^{230} \mathrm{Th} / \mathrm{U}$ age $(15.5 \pm 0.2 \mathrm{ka})$ was obtained for aragonite cement sampled from Flare site 7. This isochron age constitutes a minimum estimate for carbonate formation at Flare site 7, since it is derived from the later diagenetic cement (Fig. 3E). Bulk-rock samples from Flare sites 7 and 6 yielded similar isochron ages $(16 \pm 8$ and $20 \pm 5 \mathrm{ka} \mathrm{BP}$, respectively), although associated with relatively large errors. Despite the uncertainties, the ${ }^{230} \mathrm{Th} / \mathrm{U}$ ages obtained from Flare sites 7 and 6 agree with the range of seep carbonate ages reported from various methane seepage locations along continental margins (e.g., Teichert et al., 2003; Feng et al., 2010; Han et al., 2014). Previous studies have suggested that seep carbonates formation was favoured during times of low eustatic sea level (e.g., Feng et al., 
2010 and references therein; Tong et al., 2013; Han et al., 2014) and that the late glacial to Holocene transition was a time of enhanced seep carbonate formation (e.g., Teichert et al., 2003; Feng et al., 2010). With regard to the associated errors of most ages, the calculated isochron ages non-OMZ carbonates should be considered with caution. Still, they suggest that the non-OMZ carbonates mainly formed during the late glacial to Holocene transition. A lower eustatic sea level than today and, thus, lower hydrostatic pressure in concert with tectonic triggering might have facilitated methane seepage from the shallow-sourced gas accumulations along the Makran continental margin, eventually inducing widespread precipitation of seep carbonates.

\subsubsection{Carbonate formation at ambient seafloor conditions}

Aragonite and Mg-calcite are the dominant carbonate minerals of the Makran continental margin seep carbonates (Table 2). The depth of carbonate precipitation in the shallow subsurface at seeps can often be assessed with the aid of carbonate mineralogy. Generally, seep carbonates comprise mainly aragonite and calcite (Mg-calcite), and to a lesser degree dolomite (e.g., Roberts and Aharon, 1994; Greinert et al., 2001; Aloisi et al., 2002; Naehr et al., 2007; Roberts et al., 2010). The geochemical environment during precipitation governs mineralogical composition. Whereas aragonite precipitation is believed to be favoured at high sulphate and oxygen concentrations, calcite and dolomite form preferably at low oxygen and sulphate levels (e.g., Burton, 1993; Greinert et al., 2001 Aloisi et al., 2002; Haas et al., 2010). However, it needs to be pointed out that the common hypothesis that sulphate ions inhibit the precipitation of calcite has been challenged (Brady et al., 1996). Instead, dolomite and magnesian calcite precipitation is rather catalysed by sulphide ions, which reduce the amount of energy required for the dehydration of magnesium ions from aqueous solution (Zhang et al., 2012, 2013). Nonetheless, this finding does not affect the 
concept that aragonite preferentially precipitates from waters of a seawater composition, whereas calcite precipitation tends to be favoured under more reducing conditions. At high methane flux, AOM often occurs at shallow sediment depth, or even at the water-sediment interface (e.g., Luff et al., 2004; Teichert et al., 2005). Consequently, AOM-produced bicarbonate ions mix with pore water of seawater-like geochemistry, i.e. high dissolved sulphate and $\mathrm{Mg}^{2+} / \mathrm{Ca}^{2+}$ ratio, but at an increased alkalinity. Burton (1993) concluded that the pore fluid chemistry largely determines the carbonate mineralogy of marine diagenetic cements. Given a primary seawater-like pore fluid composition, both aragonite and $\mathrm{Mg}$ calcite can readily precipitate at methane seeps (see also Greinert et al., 2001; Peckmann et al., 2001; Aloisi et al., 2002; Luff et al., 2004; Naehr et al., 2007). Because dissolved sulphide favours calcite precipitation, dominant microcrystalline $\mathrm{Mg}$-calcite at Flare site 7 likely formed under reducing conditions with sulphate depletion of the pore fluid.

The $\delta^{18} \mathrm{O}_{\text {carbonate }}$ values provide information on the environment of carbonate precipitation, as the ${ }^{18} \mathrm{O}$ content of seep carbonates is mainly determined by the $\delta^{18} \mathrm{O}$ values of the pore fluid and the ambient temperature (e.g., Bohrmann et al., 1998; Greinert et al., 2001; Han et al., 2004; Naehr et al., 2007). Pore fluids become ${ }^{18} \mathrm{O}$-enriched $\left(\delta^{18} \mathrm{O}_{\text {fluid }}\right)$ during clay mineral dehydration or in the course of the dissociation of gas hydrates (e.g., Davidson et al., 1983; Hesse, 2003), which results in relatively higher $\delta^{18} \mathrm{O}$ values of seep carbonates $\left(\delta^{18} \mathrm{O}_{\text {carbonate }}\right)$ as would be expected for precipitation at ambient bottom water temperature (e.g., Bohrmann et al., 1998; Greinert et al., 2001; Aloisi et al., 2002; Han et al., 2004, 2014; Naehr et al., 2007; Feng et al., 2014). In this study, the theoretical $\delta^{18} \mathrm{O}_{\text {fluid }}$ values were calculated using measured bottom water temperatures (cf. Friedman and O’Neil, 1977; Grossman and Ku, 1986; Han et al., 2004) in order to test if the carbonates precipitated from anomalously ${ }^{18} \mathrm{O}-$ enriched pore fluids. Overall, the $\delta^{18} \mathrm{O}_{\text {carbonate values mirror the decrease of bottom water }}$ temperature with depth, and do not indicate formation from anomalously ${ }^{18} \mathrm{O}$-enriched fluids. 
That is, the calculated $\delta^{18} \mathrm{O}_{\text {fluid }}$ values for the Makran continental margin carbonates range from -0.9 to $0.8 \%$ o $\mathrm{V}-\mathrm{SMOW}$, which slightly deviates from modern seawater ( $0 \%$ o SMOW). Considering that late Pleistocene seawater was about $\sim 1 \%$ heavier in $\delta^{18} \mathrm{O}_{\text {seawater }}$ $\left(\delta^{18} \mathrm{O}_{\text {seawater }}: 1.05 \pm 0.2 \%\right.$ V-SMOW; Duplessy et al., 2002) than modern seawater, calculated $\delta^{18} \mathrm{O}_{\text {fluid }}$ values of $0.8 \%$ would not account for ${ }^{18} \mathrm{O}$-enriched fluids, but agree with precipitation in equilibrium with late Pleistocene seawater. This is in accord with a shallow subsurface precipitation environment and the late glacial to Holocene carbonate ages. It also agrees with structural as well as geochemical evidence that the Makran seeps are all shallow gas-sourced systems without significant influence of deep-sourced fluids (Ding et al., 2010; Römer et al., 2012; Smith et al., 2014). On the other hand, the lowest $\delta^{18} \mathrm{O}_{\text {fluid }}$ value of $-0.9 \%$ o calculated from microcrystalline aragonite $\left(\delta^{18} \mathrm{O}_{\text {aragonite }}=1.7 \pm 0.2 ; \mathrm{n}=4\right)$ from Flare site 2 is puzzling. This $\delta^{18} \mathrm{O}_{\text {fluid }}$ value is too low compared to current or late Pleistocene seawater. Assuming a $\delta^{18} \mathrm{O}_{\text {fluid }}$ value of $0 \%$ V-SMOW (modern seawater) would translate to a formation temperature of $\sim 12^{\circ} \mathrm{C}$, which is $3.5^{\circ} \mathrm{C}$ warmer than the actual measured bottom water temperature (Table 2). Consequently, the calculated $\delta^{18} \mathrm{O}_{\text {fluid }}$ value of $-0.9 \%$ V-SMOW indicates aragonite precipitation at elevated bottom water temperatures or from ${ }^{18} \mathrm{O}$-depleted fluids. Remarkably, at this site shallow gas hydrate was present 40 to $100 \mathrm{~cm}$ below the seafloor (Bohrmann et al., 2008). The anomalously low $\delta^{18} \mathrm{O}_{\text {fluid }}$ values could be related to formation of gas hydrate, which preferentially incorporates ${ }^{18} \mathrm{O}$ and consequently reduces the ${ }^{18} \mathrm{O}$ concentration of the pore fluid (Hesse, 2003).

\subsection{Implications of lipid biomarker patterns and carbonate fabrics}

\subsubsection{Calcified microbial mats within the OMZ}


The distinct lamination of sample GeoB12353-7 at Flare site 15 within the OMZ (Fig. 3A) resembles a stromatolitic fabric and points to AOM-induced calcification within microbial mats above the sediment-water interface. Laminated fabrics occur also in other cold-seep carbonates that similarly grew into the water column as a result of AOM-induced calcification (e.g., Reitner et al., 2005; Teichert et al., 2005; Bayon et al., 2013). The microbial mats at Flare site 15 were tentatively ascribed to sulphide-oxidizing bacteria such as Beggiatoa spp. (Fischer et al., 2012), however, without taxonomic confirmation. Considering the high sulphide flux, calcification in an environment shaped by sulphide oxidation seems unlikely because oxidation of hydrogen sulphide per se would rather inhibit mat calcification by decreasing the local pH value (e.g., Cai et al., 2006; Bailey et al., 2009). On the other hand, the geochemical environment within the mat could have rapidly shifted from sulphideoxidation towards an AOM-dominated microenvironment during periods of enhanced methane flux, supporting subsequent calcification through increased alkalinity (Peckmann et al., 2004; Cai et al., 2006; Bailey et al., 2009). Unfortunately, lipid biomarkers of sulphideoxidizing bacteria (i.e. saturated and unsaturated hexadecanoic and octadecanoic fatty acids) are rather unspecific and easily degraded, and therefore unlikely to be preserved as molecular fossils (see Arning et al., 2008). Because of that it is difficult to confirm or to refute a role of sulphide-oxidizing bacteria in the generation of the laminated fabric.

High methane concentrations at the shallow seabed are more feasible during advective rather than diffusive methane flux, suggesting that mat calcification was linked to high methane flux events and favoured by the low oxygen content of the bottom water. This is also corroborated by the biomarker patterns of carbonates, showing ANME-2 characteristics (crocetane, sn2-OH-Ar/Ar above 1.5; ai/i- $\mathrm{C}_{15}$ fatty acids below 2; see Niemann and Elvert, 2008 for comparison). ANME-2 archaea are adapted to mediate AOM at such conditions (e.g., Nauhaus et al., 2005; Niemann and Elvert, 2008). High contents of ANME-2 
biomarkers and petrography results further support a microbial origin of the laminae (Table 4). For example, clotted microcrystalline aggregates are typical microfabrics of calcified microbial mats (e.g., Riding, 2000), and the intense autofluorescence (Fig. 4B) is typical for high organic matter content of micrite resulting from organomineralization (Neuweiler et al., 2000). Consequently, AOM-induced calcification of microbial mats above the sediment-water interface is the most likely cause of the observed laminated fabric below an oxygen-depleted water column.

\subsubsection{Homogeneous mudstone layer}

The cm-thin microcrystalline aragonite cemented sediment layer at Flare site 2 (Figs. 2B; 3B) has been distorted by an unknown process. A predominance of the ANME-1/DSS consortium mediating AOM at low methane concentrations (low sn2-OH-Ar/Ar ratio and high ai/i- $\mathrm{C}_{15}$ fatty acid ratio; see Niemann and Elvert, 2008) suggests formation during diffusive rather than advective fluid flow. In contrast to the sampled carbonate, the uppermost sediment at Flare site 2 was actually dominated by ANME-2 archaea (Yoshinaga et al., 2012). Remarkably, ANME-2 archaea typically dominate at sites characterized by advective seepage (e.g., Peckmann et al., 2009; Haas et al., 2010; Birgel et al., 2011; Natalicchio et al., 2015). A plausible scenario for breakage of the slabs may be presented by seep carbonate formation itself. With progressive cementation the permeability of the sediment decreased significantly (see Luff et al., 2004), while increasing supply of methane from below also increased the pore pressure underneath the cemented layer, causing eventually break-up of the impermeable layer and deformation of the seafloor (e.g., Bahr et al., 2009). Similar seal-and-break processes have been suggested to explain the formation of pockmarks (Hovland et al., 1987; Matsumoto, 1990; Bahr et al., 2010; Marcon et al., 2014). 


\subsubsection{Intraformational breccias of the non-OMZ sites}

The widespread carbonate crusts of the non-OMZ sites share in common their brecciated fabrics. The earlier cemented sediment matrix was fragmented into clasts and subsequently recemented by radial-fibrous cement (Fig. 3). Brecciated fabrics of cold-seep carbonates are ascribed to three processes, (1) seal-and-break due to excess pore pressure, (2) tectonic movement inducing slumping of semi-lithified sediment, and (3) sediment fracturing caused by gas hydrate growth within the sediment (Hovland et al., 1987; Bohrmann et al., 1998; Greinert et al., 2001; Bahr et al., 2010). Given the convergent tectonic setting and the water depths of the non-OMZ seeps being located well within the gas hydrate stability zone, all processes seem feasible causes of the brecciated fabrics. Subduction-related earthquakes in the past may have triggered the destabilization of gas hydrate-bearing sediments (Fischer et

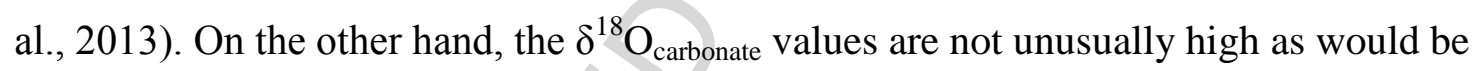
expected for carbonates formed during gas hydrate dissociation (e.g., Bohrmann et al., 1998; Greinert et al., 2001; Aloisi et al., 2002). A prerequisite for the preceding gas hydrate formation in the sediment would be the presence of methane in concentrations exceeding solubility. High methane concentrations in turn would be favourable for ANME-2/DSS consortia. Indeed, the observed lipid patterns show chiefly ANME-2/DSS characteristics, however, the sn $2 \mathrm{OH}-\mathrm{Ar} / \mathrm{Ar}$ ratio in the carbonate from Flare site 6 may also be indicative of ANME-1/DSS; the same holds true for the $a i / i-\mathrm{C}_{15}$ fatty acid ratio of Flare site 7 . Similar hybrid patterns, comprising predominantly ANME-2 signatures but also indicating significant input of ANME-1 were found in seep carbonates from Mississippi Canyon, Gulf of Mexico, and were ascribed to changes of the seepage flux in the course of carbonate formation (Feng et al., 2014). Such a scenario could also apply for the samples from Flare sites 6 and 7. However, due to the bulk-rock nature of the biomarker samples, a putative sequence of flux regimes remains unresolved. 


\subsection{Signatures of aerobic methanotrophy preserved in the non-OMZ carbonates}

Molecular fossils of aerobic methanotrophic bacteria (MOX) were preserved in the mineral matrix of the non-OMZ samples only. BHPs, especially those containing one amine functionality, are among the most specific MOX biomarkers in the non-OMZ carbonates (Table 4; e.g., Talbot and Farrimond, 2007). The BHPs are predominated by ${ }^{13} \mathrm{C}$-depleted aminotetrol and smaller amounts of aminotriol, accompanied by the less specific $\mathrm{C}_{32}$ hopanoids and diplopterol (Table 5). Whereas aminotriol may also be produced by other bacteria, such as sulphate-reducing bacteria and anoxygenic phototrophic bacteria (e.g., Blumenberg et al., 2004; Rashby et al., 2007), aminotetrol is only produced in significant amounts by aerobic methanotrophic bacteria. A similar suite of BHPs interpreted to be derived from aerobic methanotrophic bacteria was found in seep carbonates from the Gulf of Mexico, though these compounds had less negative $\delta^{13} \mathrm{C}$ values (Birgel et al., 2011). Because the OMZ samples (1) did not show similar ${ }^{13} \mathrm{C}$-depletion of hopanoids as found for the nonOMZ samples and (2) the overall contents of BHPs were lower and the distribution of BHPs was significantly different from the patterns of the non-OMZ sites, aerobic methanotrophic bacteria most likely were not among the dominant producers of hopanoids under the given oxygen-restricted conditions.

Interestingly, only one example of BHPs of aerobic methanotrophic bacteria from seep carbonates has been described (Birgel et al., 2011), but other, more resistant markers of aerobic methanotrophs such as ${ }^{13} \mathrm{C}$-depleted $3 \beta$-methylated hopanoids and 4-methylated steranes and sterols have been described more often from methane-seep sediments and carbonates (e.g., Birgel and Peckmann, 2008; Elvert and Niemann, 2008; Bouloubassi et al., 2009; Birgel et al., 2011; Natalicchio et al., 2015). The finding of strongly ${ }^{13} \mathrm{C}$-depleted BHPs 
within the non-OMZ seep carbonates of the Makran continental margin suggests that either less reducing conditions or intermittent microaerophilic conditions are common at seeps close to the sites of carbonate precipitation, augmenting previous evidence (Matsumoto, 1990; Peckmann and Thiel, 2004; Birgel and Peckmann, 2008; Birgel et al., 2011; Feng et al., 2013; Natalicchio et al., 2015). Such an interpretation agrees with the occurrence of corrosion surfaces in some of the non-OMZ carbonate samples (Himmler et al., 2010), whereas no corrosion features were observed in the OMZ carbonates. Corrosion of carbonate at active seeps is believed to be caused by aerobic, bacterial methane oxidation and possibly sulphide oxidation (Matsumoto, 1990; Himmler et al., 2011). An alternative explanation for the occurrence of the BHPs assigned to MOX in carbonates that formed below an oxygenated water body could be the presence of abundant bathymodiolin mussels at the studied seeps. Apart from commonly harbouring thiotrophic endosymbionts, particularly seep dwelling bathymodiolin mussels harbour endosymbiotic MOX in their gills (Duperron et al., 2009; Kellermann et al., 2012). However, it seems unlikely that lipids of endosymbiotic methanotrophs survive the decay of mussel tissue and end up in carbonates; even more so since the taphonomy of mussel tissue is unlikely to facilitate carbonate precipitation.

\subsection{Carbon partitioning at the non-OMZ seeps: clues from carbon fractionation patterns}

The strongly ${ }^{13} \mathrm{C}$-depletd carbonates (Flare site 11: $-46.2 \pm 3.3 \%$, $\mathrm{n}=11$; Flare site 6 : $-49.7 \pm 3.3 \%, \mathrm{n}=12$ ) and the associated lipid biomarkers (Table 4) point to biogenic methane

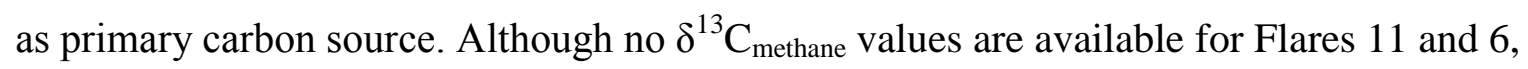
biogenic methane is also suggested as dominant carbon source at these non-OMZ sites. A comparison of the $\Delta \delta^{13} \mathrm{C}$ between methane, carbonates, and lipid biomarkers helps to assess the methane source at Flare sites 11 and 6. 
Seep carbonates typically show more positive $\delta^{13} \mathrm{C}$ values than the parent methane, caused by mixing of AOM-produced ${ }^{13} \mathrm{C}$-depleted DIC with ${ }^{13} \mathrm{C}$-rich seawater-derived DIC during carbonate precipitation (e.g., Peckmann and Thiel, 2004; Roberts et al., 2010). Based

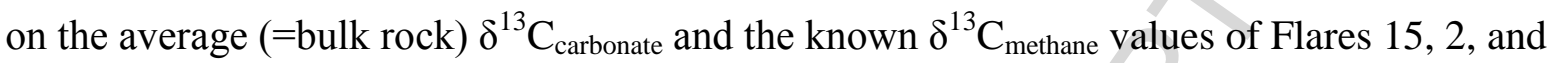
7, a $\Delta \delta^{13} \mathrm{C}_{\text {methane-carbonate }}$ of $-20.0 \pm 1.9 \%$ ( $\left.\mathrm{n}=3\right)$ is estimated (Table 6). Assuming a similar $\Delta \delta^{13} \mathrm{C}_{\text {methane-carbonate }}$ for Flares 11 and 6 , the calculated $\delta^{13} \mathrm{C}_{\text {methane value (Flare } 11 \approx-64 \% \text {; }}$ Flare $6 \approx-70 \%$ ) has a biogenic isotopic signature as well $\left(\delta^{13} \mathrm{C}_{\text {methane }}\right.$ below $-50 \%$; Whiticar, 1999).

Fractionation patterns between methane and AOM-specific lipid biomarkers were previously used to elucidate the putative methane source (Niemann and Elvert, 2008). It was shown that ANME-1 and ANME-2 communities exhibit diagnostic carbon fractionation between their lipid biomarkers and parent methane. In particular, ANME-2 lipids show an offset of about $-50 \%$ o $\left(\Delta \delta^{13} \mathrm{C}_{\mathrm{ANME}-2-\text { methane }}\right)$, whereas the $\Delta \delta^{13} \mathrm{C}$ for ANME-1 is slightly less $(-30 \%)$. The sampled carbonates at the Makran seeps contained mostly lipids of ANME2/DSS consortia, except for Flare 2 where ANME-1/DSS dominate. Based on the measured

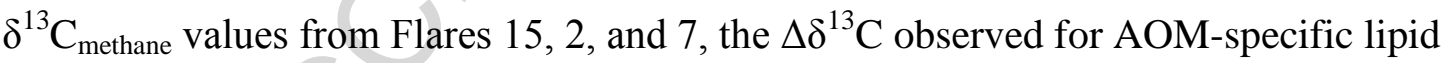
biomarkers is consistent with the expected fractionation (Table 6). In particular, the $\delta^{13} \mathrm{C}$ values for $s n 2 \mathrm{OH}$-archaeol of the ANME-2 dominated samples of Flares 11 and 6 , a $\Delta \delta^{13} \mathrm{C}$ of

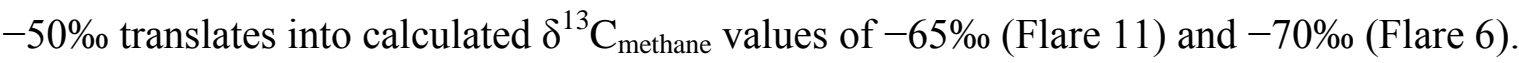

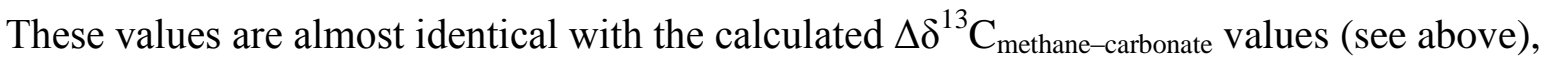
supporting biogenic methane as dominant carbon source for Flares 11 and 2.

More evidence on the methane source provide compound-specific $\delta^{13} \mathrm{C}$ values of the aerobic methanotrophs $\left(\delta^{13} \mathrm{C}_{\mathrm{MOX}}\right)$. Methanotrophic bacteria use two different pathways to assimilate carbon, namely (1) the ribulose monophosphate (RuMP) pathway, or (2) the serine pathway (Hanson and Hanson, 1996), which result in different carbon fractionation for the 
produced cell lipids (Jahnke et al., 1999). Methanotrophs that use the RuMP pathway, ascribed to type I/X methanotrophs show a relatively stronger fractionation, i.e. stronger ${ }^{13} \mathrm{C}$ depletion of the lipids compared to the oxidized methane. In contrast, carbon fractionation of type II methanotrophs that use the serine pathway is markedly less pronounced (Jahnke et al., 1999). With regard to the low $\delta^{13} \mathrm{C}$ values of the BHPs from Flares 11, 7, and 6 (Table 5), type I/X methanotrophs are the most likely producers of these compounds. A comparison of

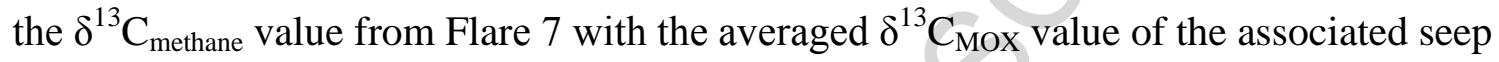

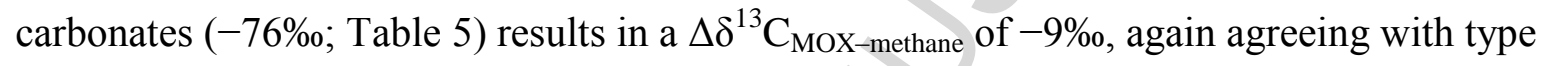
I/X methanotrophs as producers. Considering that the seep carbonates from Flare sites 11 and 6 yielded equally negative $\delta^{13} \mathrm{C}_{\text {MOX }}$ values (Table 5), a similar fractionation $\Delta \delta^{13} \mathrm{C}_{\text {MOX-methane }}$

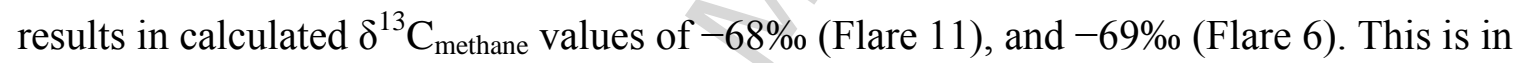

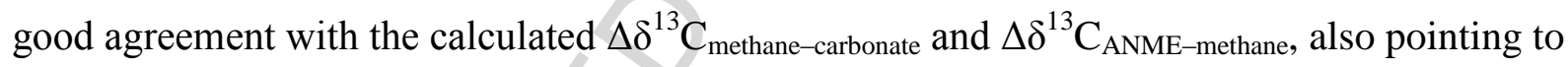
a biogenic methane source.

The observed coherency of the carbon fractionation patterns suggests that the $\delta^{13} \mathrm{C}_{\text {methane }}$ value can be estimated from the different $\Delta \delta^{13} \mathrm{C}$ values $\left(\Delta \delta^{13} \mathrm{C}_{\text {methane-carbonate, }} \Delta \delta^{13} \mathrm{C}_{\mathrm{ANME}-}\right.$

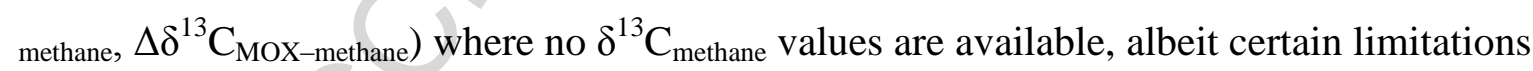
including a possible change in the isotopic composition of methane in the life span of a seep. Due to an unknown and not necessarily constant extent of admixture of non-AOM derived DIC during carbonate precipitation, the $\Delta \delta^{13} \mathrm{C}_{\text {methane-carbonate }}$ is not as accurate as the estimate

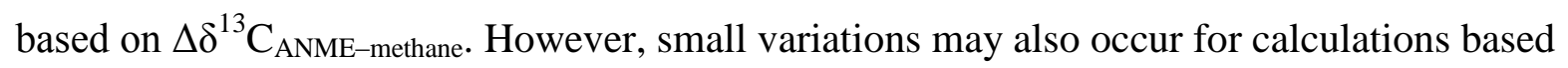
on the isotopic composition of AOM-specific lipid biomarkers, in particular when significant input of non-AOM lipids from the water column dilute the benthic AOM signal. It is

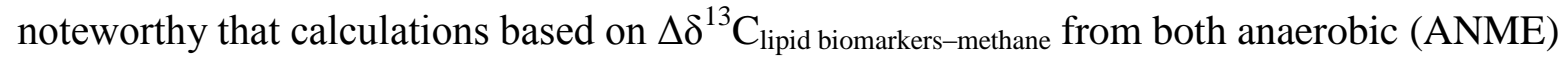
and aerobic methanotrophs (MOX) yielded consistent $\delta^{13} \mathrm{C}_{\text {methane values for the studied }}$ Makran continental margin seeps. This implies that both groups of microorganisms were 
coevally active, or alternatively that the stable carbon isotopic composition of methane was constant over the lifespan of the non-OMZ seeps.

\section{Conclusions}

1. On the Makran convergent margin, methane seeps within the oxygen minimum zone (OMZ) are dominated by microbial communities, whereas below the OMZ in fully oxic waters chemosymbiotic bivalves (bathymodiolin mussels, vesicomyid clams), tubeworms, and galatheid crabs occur as well.

2. Carbonate deposits sampled from five methane seeps reveal different fabrics, reflecting different environmental conditions during carbonate formation at or just below the sediment surface: (1) stromatolitic carbonates formed within the oxygen minimum zone at the seabed, growing into the oxygen-depleted water column, whereas (2) homogeneous and brecciated carbonates formed below the sediment surface. The latter formed in the shallow subsurface in close contact to seawater, indicated by dominantly aragonitic mineralogies and $\delta^{18} \mathrm{O}_{\text {carbonate values that reflect }}$ precipitation in equilibrium with bottom water, also mirroring the decreasing water temperatures at the five study sites with increasing depth.

3. The ${ }^{230} \mathrm{Th} / \mathrm{U}$ age of pure aragonite points to a late Pleistocene carbonate formation of the non-OMZ carbonates. Petrographic features indicate a somewhat younger age of the OMZ deposits that only comprise a single early diagenetic carbonate cement phase, whereas the non-OMZ deposits show at least two phases of cementation: (1) an early stage of sediment cementation by microcrystalline cement, followed by (2) later growth of radial-fibrous cement filling voids and re-cementing intraformational clasts. 
4. The $\delta^{13} \mathrm{C}$ values of methane in seeping gas substantiate the prevalence of biogenic methane sources in the deeper subsurface. Biogenic methane as dominant carbon source is supported by exclusively negative $\delta^{13} \mathrm{C}$ values of carbonates at all sites. Extremely ${ }^{13} \mathrm{C}$-depleted AOM-specific lipid biomarkers revealed that ANME-2/DSS as well as ANME-1/DSS consortia oxidized methane.

5. Lipid biomarkers of aerobic methanotrophic bacteria, exclusively found in carbonates that formed at the deeper water seeps below an oxic water body, indicate less reducing conditions or intermittent microaerophilic conditions during carbonate precipitation.

6. Carbon fractionation patterns between methane, carbonates, and carbonate-associated lipid biomarkers confirm that biogenic methane is the dominant carbon source at the investigated seeps. These patterns prove to be robust proxies to calculate the isotopic composition of methane. This approach has great potential to assess the carbon isotopic composition of methane at ancient seeps if lipid biomarkers are preserved.

\section{Acknowledgements}

Professional support at sea by the master and the crew of R/V METEOR, and skilful operation of the ROV MARUM-QUEST 4000 m team during expedition M74/3 is greatly acknowledged. Karin Zonneveld is thanked for water column sample analyses during M74/3. Giovanni Gattolin is thanked for thorough lab-work assistance. Special thanks to Monika Segl for stable isotope analysis, Julius S. Lipp for support during the analysis of BHPs, Christoph Vogt for XRD measurements, and Sebastian Flotow (all MARUM) for the preparation of excellent large thin sections. Analytical support by Emmanuel Ponzevera and Yoan Germain at the Pôle Spectrométrie Océan (Brest, France) is greatly appreciated. Comments by two anonymous referees helped improve the manuscript. This study was funded through the DFG- 
Research Center/Cluster of Excellence „The Ocean in the Earth System“ and by an IFREMER post-doc grant (TH).

\section{References}

Aloisi, G., Bouloubassi, I., Heijs, S.K., Pancost, R., Pierre, C., Sinninghe Damsté, J.S., Gottschal, J.C., Forney, L.J., Rouchy, J.-M., 2002. $\mathrm{CH}_{4}$-consuming microorganisms and the formation of carbonate crusts at cold seeps. Earth and Planetary Science Letters 203, 195-203.

Arning, E.T., Birgel, D., Schulz-Vogt, H.N., Holmkvist, L., Jørgensen, B.B., Larson, A., Peckmann, J., 2008. Lipid biomarker patterns of phosphogenic sediments from upwelling Regions. Geomicrobiology Journal 25, 69-82.

Barnes, R.O., Goldberg, E.D., 1976. Methane production and consumption in anaerobic marine sediments. Geology 4, 297-300.

Bahr, A., Pape, T., Bohrmann, G., Mazzini, A., Haeckel, M., Reitz, A., Ivanov, M., 2009. Authigenic carbonate precipitates from the NE Black Sea: a mineralogical, geochemical, and lipid biomarker study. International Journal of Earth Sciences 98, 677-695.

Bahr, A., Pape, T., Abegg, F., Bohrmann, G., van Weering T.C.E., Ivanov, M.K., 2010. Authigenic carbonates from the eastern Black Sea as an archive for shallow gas hydrate dynamics-Results from the combination of CT imaging with mineralogical and stable isotope analyses. Marine and Petroleum Geology 27, 1819-1829.

Bailey, J.V., Orphan, V.J., Joye, S.B., Corsetti, F.A., 2009. Chemotrophic microbial mats and their potential for preservation in the rock record. Astrobiology 9, 843-859.

Bayon, G., Henderson, G.M., Bohn, M., 2009. U-Th stratigraphy of a cold seep carbonate crust. Chemical Geology 260, 47-56. 
Bayon, G., Dupré, S., Ponzevera, E., Etoubleau, J., Chéron, S., Pierre, C., Mascle, J., Boetius, A., de Lange, G.J., 2013. Formation of carbonate chimneys in the Mediterranean Sea linked to deep-water oxygen depletion. Nature Geosciences 6, 755-760.

Berner, R.A., 1980. Early Diagenesis - A Theoretical Approach. Princeton University Press, Princeton.

Birgel, D., Peckmann, J., 2008. Aerobic methanotrophy at ancient marine methane-seeps: A synthesis. Organic Geochemistry 39, 1659-1667.

Birgel, D., Thiel, V., Hinrichs, K.-U., Elvert, M., Campbell, K.A., Reitner, J., Farmer, J.D., Peckmann, J., 2006. Lipid biomarker patterns of methane-seep microbialites from the Mesozoic convergent margin of California. Organic Geochemistry 37, 1289-1302.

Birgel, D., Elvert, M., Han, X., Peckmann, J., 2008. ${ }^{13}$ C-depleted biphytanic diacids as tracers of past anaerobic oxidation of methane. Organic Geochemistry 39, 152-166.

Birgel, D., Feng, D., Roberts, H.H., Peckmann, J., 2011. Changing redox conditions at cold seeps as revealed by authigenic carbonates from Alaminos Canyon, northern Gulf of Mexico. Chemical Geology 285, 82-96.

Blumenberg, M., Seifert, R., Reitner, J., Pape, T., Michaelis, W., 2004. Membrane lipid patterns typify distinct anaerobic methanotrophic consortia. Proceedings of the National Academy of Sciences of the United States of America 101, 11111-11116.

Boetius, A., Ravenschlag, K., Schubert, C.J., Rickert, D., Widdel, F., Gieseke, A., Amann, R., Jørgensen, B.B., Witte, U., Pfannkuche, O., 2000. A marine microbial consortium apparently mediating anaerobic oxidation of methane. Nature 407, 623-626.

Bohrmann, G., Greinert, J., Suess, E., Torres, M., 1998. Authigenic carbonates from the Cascadia subduction zone and their relation to gas hydrate stability. Geology 26, 647650. 
Bohrmann, G., and cruise participants, 2008. Report and preliminary results of R/V METEOR Cruise M74/3, Fujairah-Male, 30 October - 28 November, 2007. Cold seeps of the Makran Subduction Zone (Continental Margin of Pakistan). Berichte Fachbereich Geowissenschaften, Universität Bremen, No. 266, pp.161, Bremen.

Bouloubassi, I., Nabais, E., Pancost, R.D., Lorre, A., Taphanel, M.-H., 2009. First biomarker evidence for methane oxidation at cold seeps in the Southeast Atlantic (REGAB pockmark). Deep Sea Research II 56, 2239-2247.

Brady, P.V., Krumhansl, J.L., Papenguth, H.W., 1996. Surface complexation clues to dolomite growth. Geochimica et Cosmochimica Acta 60, 727-731.

Burton, E.A., 1993. Controls on marine carbonate cement mineralogy: Review and reassessment. Chemical Geology 105, 163-179.

Cai, W.-J., Chen, F., Powell, E.N., Walker, S.E., Parsons-Hubbard, K.K., Staff, G.M., Wang, Y., Ashton-Alcox, K.A., Callender, W.R., Brett, C.E., 2006. Preferential dissolution of carbonate shells driven by petroleum seep activity in the Gulf of Mexico. Earth and Planetary Science Letters 248, 227-243.

Cheng, H., Edwards, R.L., Hoff, J., Gallup, C.D., Richards, D.A., Asmeron, Y., 2000. The half-lives of ${ }^{234} \mathrm{U}$ and ${ }^{230} \mathrm{Th}$. Chemical Geology 169, 17-33.

Crémière, A., Bayon, G., Ponzevera, E., Pierre, C., 2013. Paleo-environmental controls on cold seep carbonate authigenesis in the Sea of Marmara. Earth and Planetary Science Letters 376, 200-211.

Davidson, D.W., Leaist, D.G., Hesse, R., 1983. Oxygen-18 enrichment in the water of a clathrate hydrate. Geochimica et Cosmochimca Acta 47, 2293-2295.

Ding, F., Spiess, V., Fekete, N., Murton, B., Brüning, M., Bohrmann G., 2010. Interaction between accretionary thrust faulting and slope sedimentation at the frontal Makran 
accretionary prism and its implications for hydrocarbon fluid seepage. Journal of

Geophysical Research 115, B08106, doi:10.1029/2008JB006246.

Duperron, S., Lorion, J., Samadi, S., Gros, O., Gaill, F., 2009. Symbioses between deep-sea mussels (Mytilidae: Bathymodiolinae) and chemosynthetic bacteria: diversity, function and evolution. Comptes Rendus Biologies 332, 298-310.

Duplessy, J.-C., Labeyrie, L., Waelbroeck, C., 2002. Constraints on the ocean oxygen isotopic enrichment between the Last Glacial Maximum and the Holocene: paleoceanographic implications. Quaternary Science Reviews 21, 315-330.

Edwards, R.L., Chen, J.H., Wasserburg, G.R., 1986. ${ }^{238} \mathrm{U}-{ }^{234} \mathrm{U}-{ }^{230} \mathrm{Th}-{ }^{232} \mathrm{Th}$ systematic and the precise measurement of time over the past 500,000 years. Earth and Planetary Science Letters 81, 175-192.

Elvert, M., Niemann, H., 2008. Occurrence of unusual steroids and hopanoids derived from aerobic methanotrophs at an active marine mud volcano. Organic Geochemistry 39, $167-177$.

Farhoudi, G., Karig, D.E., 1977. Makran of Iran and Pakistan as an active arc system. Geology 5, 664-668.

Feng, D., Chen, D., Peckmann, J., 2009. Rare earth elements in seep carbonates as tracers of variable redox conditions at ancient hydrocarbon seeps. Terra Nova 21, 49-56.

Feng, D., Roberts, H.H., Cheng, H., Peckmann, J., Bohrmann, G., Edwards, R.L., Chen, D., 2010. U/Th dating of cold-seep carbonates: An initial comparison. Deep-Sea Research II 57, 2055-2060.

Feng, D., Lin, Z., Bian, Y., Chen, D., Peckmann, J., Bohrmann, G., Roberts, H.H., 2013. Rare earth elements of seep carbonates: Indication for redox variations and microbiological processes at modern seep sites. Journal of Asian Earth Sciences 65, 27-33. 
Feng, D., Birgel, D., Peckmann, J., Roberts, H.H., Joye, S.B., Sassen, R., Liu, X.-L., Hinrichs, K.-U., Chen, D., 2014. Time integrated variation of sources of fluids and seepage dynamics archived in authigenic carbonates from Gulf of Mexico Gas Hydrate Seafloor Observatory. Chemical Geology 385, 129-139,

Fischer, D., Sahling, H., Nöthen, K., Bohrmann, G., Zabel, M., Kasten, S., 2012. Interaction between hydrocarbon seepage, chemosynthetic communities, and bottom water redox at cold seeps of the Makran accretionary prism: insights from habitat-specific pore water sampling and modeling. Biogeosciences 9, 2013-2031.

Fischer, D., Mogollón, J.S., Strasser, M., Pape, T., Bohrmann, G., Fekete, N., Spiess, V., Kasten, S., 2013. Subduction zone earthquake as potential trigger of submarine hydrocarbon seepage. Nature Geoscience 6, 647-651.

Formolo, M.J., Lyons, T.W., Zhang, C., Kelley, C., Sassen, R., Horita, J., Cole, D.R., 2004. Quantifying carbon sources in the formation of authigenic carbonates at gas hydrate sites in the Gulf of Mexico. Chemical Geology 205, 253-264.

Friedman, I., O’Neil, J.R., 1977. Compilation of stable isotope fractionation factors of geochemical interest. In: M. Fleischer (Ed.), Data of Geochemistry. United States Geological Survey Professional Paper, 440KK, 12 p.

Golonka, J., 2004. Plate tectonic evolution of the southern margin of Eurasia in the Mesozoic and Cenozoic. Tectonophysics 381, 235-273.

Greinert, J., Bohrmann, G., Suess, E., 2001. Gas hydrate associated carbonates and methaneventing at Hydrate Ridge; classification, distribution, and origin of authigenic lithologies. In: Paull, C. K., Dillon, W. P. (Eds.), Natural Gas Hydrates; Occurrence, Distribution, and Detection, vol. 124. Geophysical Monograph, pp. 99-113.

Grossman, E.L., Ku, T.-L., 1986. Oxygen and carbon isotope fractionation in biogenic aragonite: temperature effects. Chemical Geology 59, 59-74. 
Haas, A., Peckmann, J., Elvert, M., Sahling, H., Bohrmann, G., 2010. Patterns of carbonate authigenesis at the Kouilou pockmarks on the Congo deep-sea fan. Marine Geology $268,129-136$.

Han, X., Suess, E., Sahling, H., Wallmann, K., 2004. Fluid venting activity on the Costa Rica margin: new results from authigenic carbonates. International Journal of Earth Sciences 93, 595-611.

Han, X., Suess, E., Liebetrau, V., Eisenhauer, A., Huang, Y., 2014. Past methane release events and environmental conditions at the upper continental slope of the South China Sea: constraints by seep carbonates. International Journal of Earth Science 103, 18731887.

Hanson, R.S., Hanson, T.E., 1996. Methanotrophic bacteria. Microbiological Reviews 60, $439-471$.

Hesse, R., 2003. Pore water anomalies of submarine gas-hydrate zones as tool to assess hydrate abundance and distribution in the subsurface - what have we learned in the past decade? Earth-Science Reviews 61, 149-179.

Himmler, T., Bach, W., Bohrmann, G., Peckmann, J., 2010. Rare earth elements in authigenic methane-seep carbonates as tracers for fluid composition during early diagenesis. Chemical Geology 277, 126-136.

Himmler, T., Brinkmann, F., Bohrmann, G., Peckmann, J., 2011. Corrosion patterns of seepcarbonates from the eastern Mediterranean Sea, Terra Nova 23, 206-212.

Hinrichs, K.-U., Hayes, J.M., Sylva, S.P., Brewer, P.G., DeLong, E.F., 1999. Methaneconsuming archaebacteria in marine sediments. Nature 398, 802-805.

Hoehler, T.M., Alperin, M.J., Albert, D.B., Martens, C.S., 1994. Field and laboratory studies of methane oxidation in an anoxic marine sediment: evidence for a methanogen-sulfate reducer consortium. Global Biogeochemical Cycles 8, 451-463. 
Hovland, M., Talbout, M., Qvale, H., Olausson, S., Aasberg, L., 1987. Methane-related carbonate cements in pockmarks of the North Sea. Journal of Sedimentary Petrology 57, 881-892.

Jahnke, L.L., Summons, R.E., Hope, J.M., Des Marais, D.J., 1999. Carbon isotopic fractionation in lipids from methanotrophic bacteria II: the effects of physiology and environmental parameters on the biosynthesis and isotopic signatures of biomarkers. Geochimica et Cosmochimica Acta 63, 79-93.

Judd, A., Hovland, M., 2009. Seabed Fluid Flow. Cambridge University Press. 492 pp.

Kellermann, M.Y., Schubotz, F., Elvert, M., Lipp, J.S., Birgel, D., Prieto-Mollar, X., Dubilier, N., Hinrichs, K.-U., 2012. Symbiont-host relationships in chemosynthetic mussels: A comprehensive lipid biomarker study. Organic Geochemistry 43, 112-124.

Knittel, K., Lösekann, T., Boetius, A., Kort, R., Amann, R., 2005. Diversity and distribution of methanotrophic archaea at cold seeps. Applied and Environmental Microbiology 71, $467-479$.

Kopp, C., Fruehn, J., Flueh, E.R., Reichert, C., Kukowski, N., Bialas, J., Klaeschen, D., 2000. Structure of the Makran subduction zone from wide-angle and reflection seismic data. Tectonophysics 329, 171-191.

Kukowski, N., Schillhorn, T., Huhn, K., von Rad, U., Husen, S., Flueh, E.R., 2001. Morphotectonics and mechanics of the central Makran accretionary wedge off Pakistan. Marine Geology 173, 1-19.

Kulm, L.D., Suess, E., Moore, J.C., Carson, B., Lewis, B.T., Ritger, S.D., Kadko, D.C., Thornburg, T.M., Embley, R.W., Rugh W.D., Massoth, G.J., Langseth, M.G., Cochrane, G.R., Scamman, R.L., 1986. Oregon subduction Zone: venting, fauna, and carbonates. Science 231, 561-566. 
Ludwig, K.R., 2009. Isoplot v. 3.71: A geochronological toolkit for Microsoft Excel.

Berkeley Geochronology Center Special Publication, Berkeley, California. http://www.bgc.org/isoplot_etc/isoplot.html

Luff, R., Wallmann, K., 2003. Fluid flow, methane fluxes, carbonate precipitation and biogeochemical turnover in gas hydrate-bearing sediments at Hydrate Ridge, Cascadia Margin: Numerical modeling and mass balances. Geochimica et Cosmochimica Acta 67, 3403-3421.

Luff, R., Wallmann, K., Aloisi, G., 2004. Numerical modeling of carbonate crust formation at cold vent sites: significance for fluid and methane budgets and chemosynthetic biological communities. Earth and Planetary Science Letters 221, 337-353.

Marcon, Y., Ondreas, H., Sahling, H., Bohrmann, G., Olu, K., 2014. Fluid flow regimes and growth of a giant pockmark. Geology 42, 63-66.

Matsumoto, R., 1990. Vuggy carbonate crust formed by hydrocarbon seepage on the continental shelf of Baffin Island, northeast Canada. Geochemical Journal 24, 143-158.

Milucka, J., Ferdelman, T.G., Polerecky, L., Franzke, D., Wegener, G., Schmid, M., Lieberwirth, I., Wagner, M., Widdel, F., Kuypers, M.M.M., 2012. Zero-valent sulphur is a key intermediate in marine methane oxidation. Nature 491, 541-546.

Müller, G., Gastner, M., 1971. The 'Karbonat-Bombe', a simple device for the determination of the carbonate content in sediments, soils and other materials. Neues Jahrbuch für Mineralogie 10, 466-469.

Natalicchio, M., Peckmann, J., Birgel, D., Kiel, S., 2015. Seep deposits from northern Istria, Croatia: a first glimpse into the Eocene seep fauna of the Tethys region. Geological Magazine 152, 449-459.

Naehr, T.H., Eichhubl, P., Orphan, V.J., Hovland, M., Paull, C.K., Ussler III, W., Lorenson, T.D., Greene, H.G., 2007. Authigenic carbonate formation at hydrocarbon seeps in 
continental margin sediments: A comparative study. Deep-Sea Research II 54, 1268 1291.

Nauhaus, K., Treude, T., Boetius, A., Krüger, M., 2005. Environmental regulation of the anaerobic oxidation of methane: a comparison of ANME-I and ANME-II communities. Environmental Microbiology 7, 98-106.

Neunlist, S., Holst, O., Rohmer, M., 1985. Prokaryotic triterpenoids. The hopanoids of the purple non-sulfur bacterium Rhodomicrobium vannielii: an aminotriol and its aminoacyl derivatives, N-tryptophanyl and N-ornithyl aminotriol. European Journal of Biochemistry 147, 561-568.

Neuweiler, F., Rutsch, M., Geipel, G., Reimer, A., Heise, K.-H., 2000. Soluble humic substances from in situ precipitated microcrystalline calcium carbonate, internal sediment, and spar cement in a Cretaceous carbonate mud-mound. Geology 28, 851854.

Niemann, H., Elvert, M., 2008. Diagnostic lipid biomarker and stable carbon isotope signatures of microbial communities mediating the anaerobic oxidation of methane with sulphate. Organic Geochemistry 39, 1668-1677.

Olson, D.B., Hitchcock, G.L., Fine, R.A., Warren, B.A., 1993. Maintenance of the lowoxygen layer in the central Arabian Sea. Deep-Sea Research II 40, 673-585.

Pape, T., Blumenberg, M., Seifert, R., Egorov, V.N., Gulin, S.B., Michaelis, W., 2005. Lipid geochemistry of methane-seep-related Black Sea carbonates. Palaeogeography, Palaeoclimatology, Palaeoecology 227, 31-47.

Pape, T., Bahr, A., Rethemeyer, J., Kessler, J.D., Sahling, H., Hinrichs, K.-U., Klapp, S.A., Reeburgh, W.S., Bohrmann, G., 2010. Molecular and isotopic partitioning of lowmolecular weight hydrocarbons during migration and gas hydrate precipitation in deposits of a high-flux seepage site. Chemical Geology 269, 350-363. 
Paull, C.K., Chanton, J.P., Neumann, A.C., Coston, J.A., Martens, C.S., Showers, W., 1992. Indicators of methane derived carbonates and chemosynthetic organic carbon deposits; examples from the Florida Escarpment. Palaios 7, 361-375.

Peckmann, J., Thiel, V., 2004. Carbon cycling at ancient methane-seeps. Chemical Geology $205,443-467$.

Peckmann, J., Reimer, A., Luth, U., Luth, C., Hansen, B.T., Heinicke, C., Hoefs, J., Reitner, J., 2001. Methane-derived carbonates and authigenic pyrite from the northwestern Black Sea. Marine Geology 177, 129-150.

Peckmann, J., Thiel, V., Reitner, J., Taviani, M., Aharon, P., Michaelis, W., 2004. A microbial mat of a large sulfur bacterium preserved in a Miocene methane-seep limestone. Geomicrobiology Journal 21, 247-255.

Peckmann, J., Birgel, D., Kiel, S., 2009. Molecular fossils reveal fluid composition and flow intensity at a Cretaceous seep. Geology 37, 847-850.

Qasim, S.Z., 1982. Oceanography of the northern Arabian Sea. Deep-Sea Research A A29, $1041-1068$.

Rashby, S.E., Sessions, A.L., Summons, R.E., Newman, D.K., 2007. Biosynthesis of 2methylbacteriohopanepolyols by an anoxygenic phototroph. Proceedings of the National Academy of Sciences of the United States of America 104, 15099-15104.

Reichart, G.J., Lourens, J.L., Zachariasse, W.J., 1998. Temporal variability in the northern Arabian Sea Oxygen Minimum Zone (OMZ) during the last 225,000 years.

Paleoceanography 13, 607-621.

Reitner, J., Peckmann, J., Reimer, A., Schumann, G., Thiel, V., 2005. Methane-derived carbonate build-ups and associated microbial communities at cold seeps on the lower Crimean shelf (Black Sea). Facies 51, 66-79. 
Rohmer, M., Bouviernave, P., Ourisson, G., 1984. Distribution of hopanoid triterpenes in prokaryotes. Journal of General Microbiology 130, 1137-1150.

Riding, R., 2000. Microbial carbonates: the geological record of calcified bacterial-algal mats and biofilms. Sedimentology 47, 179-214.

Ritger, S., Carson, B., Suess, E., 1987. Methane-derived authigenic carbonates formed by subduction-induced pore-water expulsion along the Oregon/Washington margin. Geological Society of America Bulletin 98, 147-156.

Roberts, H.H., Aharon, P., 1994. Hydrocarbon-derived carbonate buildups of the northern Gulf of Mexico continental slope: a review of submersible investigations. Geo-Marine Letters $14,135-148$.

Roberts, H.H., Feng, D., Joye, S.B., 2010. Cold-seep carbonates of the middle and lower continental slope, northern Gulf of Mexico. Deep-Sea Research II 57, 2040-2054.

Römer, M., Sahling, H., Pape, T., Bohrmann, G., Spieß, V., 2012. Quantification of gas bubble emissions from submarine hydrocarbon seeps at the Makran continental margin offshore Pakistan. Journal of Geophysical Research: 117, C10015, doi:10.1029/2011JC007424.

Römer, M., Sahling, H., Pape, T., dos Santos Ferreira, C., Wenzhöfer, F., Boetius, A., Bohrmann, G., 2014. Methane fluxes and carbonate deposits at a cold seep area of the Central Nile Deep Sea Fan, Eastern Mediterranean Sea. Marine Geology 347, 27-42.

Rossel, P.E., Elvert, M., Ramette, A., Boetius, A., Hinrichs, K.-U., 2011. Factors controlling the distribution of anaerobic methanotrophic communities in marine environments: evidence from intact polar membrane lipids. Geochimica et Cosmochimica Acta 75, $164-184$. 
Sain, K., Minshull, T.A., Singh, S.C., Hobbs, R.W., 2000. Evidence for a thick free gas layer beneath the bottom simulating reflector in the Makran accretionary prism. Marine Geology 164, 3-12.

Schmaljohann, R., Drews, M., Walter, S., Linke, P., von Rad, U., Imhoff, J.F., 2001. Oxygenminimum zone sediments in the northeastern Arabian Sea off Pakistan: a habitat for the bacterium Thioploca. Marine Ecology Progress Series 211, 27-42.

Smith, G.L., McNeill, L.C., Henstock, T.J., Arraiz, D., Spiess, V., 2014. Fluid generation and distribution in the highest sediment input accretionary margin, the Makran. Earth and Planetary Science Letters 403, 131-143.

Solomon, E., Kastner, M., Jannasch, H., Robertson, G., Weinstein, Y., 2008. Dynamic fluid flow and chemical fluxes associated with a seafloor gas hydrate deposit on the northern Gulf of Mexico slope. Earth and Planetary Science Letters 270, 95-105.

Stadnitskaia, A., Nadezhkin, D., Abbas, B., Blinova, V., Ivanov, M.K., Sinninghe Damsté, J.S., 2008. Carbonate formation by anaerobic oxidation of methane: Evidence from lipid biomarker and fossil 16S rDNA. Geochimica et Cosmochimica Acta 72, 1824-1836.

Suess, E., 2014. Marine cold seeps and their manifestations: geological control, biogeochemical criteria and environmental conditions. International Journal of Earth Sciences 103, 1889-1916.

Talbot, H.M., Squier, A.H., Keely, B.J., Farrimond, P., 2003. Atmospheric pressure chemical ionization reversed-phase liquid chromatography/ion trap mass spectrometry of intact bacteriohopanepolyols. Rapid Communications in Mass Spectrometry 17, 728-737.

Talbot, H.M., Farrimond, P., 2007. Bacterial populations recorded in diverse sedimentary biohopanoid distributions. Organic Geochemistry 38, 1212-1225.

Teichert, B.M.A., Eisenhauer, A., Bohrmann, G., Haase-Schramm, A., Bock, B., Linke, P., 2003. U/Th systematics and ages of authigenic carbonates from Hydrate Ridge, 
Cascadia Margin: recorders of fluid flow variations. Geochimica et Cosmochimica Acta $67,3845-3857$.

Teichert, B.M.A., Bohrmann, G., Suess, E., 2005. Chemoherms on Hydrate Ridge-Unique microbially-mediated carbonate build-ups growing into the water column. Palaeogeography, Palaeoclimatology, Palaeoecology 227, 67-85.

Thiel, V., Peckmann, J., Seifert, R., Wehrung, P., Reitner, J., Michaelis, W., 1999. Highly isotopically depleted isoprenoids: Molecular markers for ancient methane venting. Geochimica et Cosmochimica Acta 63, 3959-3966.

Thiel, V., Peckmann, J., Richnow, H.H., Luth, U., Reitner, J., Michaelis, W., 2001. Molecular signals for anaerobic methane oxidation in Black Sea seep carbonates and a microbial mat. Marine Chemistry 73, 97-112.

Tong, H., Feng, D., Cheng, H., Yang, S., Wang, H., Min, A.G., Edwards, R.L., Chen, Z., Chen, D., 2013. Authigenic carbonates from seeps on the northern continental slope of the South China Sea: New insights into fluid sources and geochronology. Marine and Petroleum Geology 43, 260-271.

Torres, M.E., McManus, J., Hammond, D.E., de Angelis, M.A., Heeschen, K.U., Colbert, S.L., Tryon, M.D., Brown, K.M., Suess, E., 2002. Fluid and chemical fluxes in and out of sediments hosting methane hydrate deposits on Hydrate Ridge, OR, I: Hydrological provinces. Earth and Planetary Science Letters 201, 525-540.

Tryon, M.D., Brown, K.M., Torres, M.E., Tréhu, A.M., McManus, J., Collier, R.W., 1999. Measurements of transience and downward fluid flow near episodic methane gas vents, Hydrate Ridge, Cascadia. Geology 27, 1075-1078.

Ussler III, W., Paull, C.K., 2008. Rates of anaerobic oxidation of methane and authigenic carbonate mineralization in methane-rich deep-sea sediments inferred from models and geochemical profiles. Earth and Planetary Science Letters 299, 271-287. 
Von Rad, U., Rösch, H., Berner, U., Geyh, M., Marchig, V., Schulz, H., 1996. Authigenic carbonates derived from oxidized methane vented from the Makran accretionary prism off Pakistan. Marine Geology 136, 55-77.

Von Rad, U., Berner, U., Delisle, G., Doose-Rolinski, H., Fechner, N., Linke, P., Lückge, A., Roeser, H.A., Schmaljohann, R., Wiedicke, M., SONNE 122/130 Scientific Parties, 2000. Gas and fluid venting at the Makran accretionary wedge off Pakistan. Geo-Marine Letters 20, 10-19.

White, R.S., 1984. Active and passive plate boundaries around the Gulf of Oman, north-west Indian Ocean. Deep Sea Research 31, 31-745.

Whiticar, M.J., 1999. Carbon and hydrogen isotope systematics of bacterial formation and oxidation of methane. Chemical Geology 161, 291-314.

Wyrtki, K., 1973. Physical oceanography of the Indian Ocean. In: Zeitschelp, B. (Ed.), The Biology of the Indian Ocean. pp. 18-36. Springer, New York.

Yoshinaga, M.Y., Wörmer, L., Elvert, M., Hinrichs, K.-U., 2012. Novel cardiolipins from uncultured methane-metabolizing archaea. Archaea 2012, 9 pp.

doi:10.1155/2012/832097

Zhang, F., Xu, H., Konishi, H., Kemp, J.M., Roden, E.E., Shen, Z., 2012. Dissolved sulfidecatalyzed precipitation of disordered dolomite: Implications for the formation mechanism of sedimentary dolomite. Geochimica et Cosmochimica Acta 97, 148-165.

Zhang, F., Yan, C., Teng, H.H., Roden, E.E., Xu, H., 2013. In situ AFM observations of CaMg carbonate crystallization catalyzed by dissolved sulfide: Implications for sedimentary dolomite formation. Geochimica et Cosmochimica Acta 105, 44-55.

\section{Table captions}




\section{Table 1}

Details of sampling locations and seafloor observations; $\mathrm{OMZ}=$ oxygen minimum zone; GeoB $=$ Faculty of Geosciences, University of Bremen.

\section{Table 2}

Mineralogical composition of the samples and site-specific temperatures; GeoB = Faculty of Geosciences, University of Bremen; Ara = aragonite; $\mathrm{Cc}=$ calcite; $\mathrm{Mg}-\mathrm{Cc}=$ magnesium calcite Dol = dolomite Fsp = feldspar Chl = chlorite Mic $=$ mica $;$ n.a. = not analysed.

Table 3 Uranium and thorium contents and determined activity ratios $\left({ }^{230} \mathrm{Th} /{ }^{232} \mathrm{Th}\right)$, $\left({ }^{238} \mathrm{U} /{ }^{232} \mathrm{Th}\right) ; \mathrm{GeoB}=$ Faculty of Geosciences, University of Bremen; activity ratios $\left({ }^{232} \mathrm{Th} /\right.$ $\left.{ }^{238} \mathrm{U}\right)$ and $\left({ }^{230} \mathrm{Th} /{ }^{238} \mathrm{U}\right)$ used for calculations; ages in italics deemed inaccurate due to high initial ${ }^{232} \mathrm{Th}$ (i.e. high clay mineral content); $\delta^{234} \mathrm{U}_{\mathrm{i}}$ represents the measured activity ratios of $\left({ }^{234} U /{ }^{238} U\right)$, expressed in delta notation $\left.\delta^{234} U_{i}=\left[\left({ }^{234} U /{ }^{238} U\right)-1\right) * 1000\right]$.

Table 4 Carbonate associated lipid biomarker contents and compound-specific $\delta^{13} \mathrm{C}$ values; $\mathrm{GeoB}=$ Faculty of Geosciences, University of Bremen; OMZ = oxygen minimum zone; tr. = trace amounts; n.d. = not detected; n.m. = contents too low for measurement on GC-IRMS; $\mathrm{PMI}=$ pentamethylicosane; PMI $\Delta$ : sum of unsaturated PMI:1, :2, :3; Ar = archaeol; MAGE = monoalkyl glycerol monoether; DAGE = dialkyl glycerol diether; ${ }^{\#}$ :average $\delta^{13} \mathrm{C}$ values of all $\mathrm{PMI} \Delta$ and PMI.

Table 5 Contents of hopanoids and compound-specific $\delta^{13} \mathrm{C}$ values; GeoB = Faculty of Geosciences, University of Bremen; OMZ = oxygen minimum zone; n.d. = not detected; n.m. $=$ not measured due to low contents; tr. = trace amounts; for contents of 
bacteriohopanepolyols (BHPs) $+==$ low contents; $++=$ high contents (see Fig. 7 for more details).

Table 6 Synthesis of $\delta^{13} \mathrm{C}$ values (\%o V-PDB) and relative partitioning $\left(\Delta \delta^{13} \mathrm{C}\right)$ between methane-derived carbon and organic (lipid biomarkers) and inorganic (carbonate) species; $\mathrm{OMZ}=$ oxygen minimum zone; $\mathrm{ANME}=$ anaerobic methanotrophic archaea $\mathrm{SRB}=$ sulphate-reducing bacteria; $\mathrm{MOX}=$ aerobic methanotrophic bacteria; n.a. = not analysed; n.c. = not calculated; *adopted from Römer et al. (2012).

\section{Figure captions}

Fig. 1. Sitemap and depth profile. Upper left panel: Sketch map of the regional tectonic setting; black rectangle outlines the working area during M74/3 (OP = Omara Plate; modified after Kukowski et al. 2001); bathymetry of the Makran continental margin slope and sites where hydroacoustic anomalies caused by rising gas bubbles in the water column (named 'Flares', Bohrmann et al., 2008; Römer et al. 2012) have been detected. Locations of sampled authigenic carbonates are marked by asterisks. Lower panel: schematic cross section of the Makran continental slope highlighting the sample locations with respect to present-day seawater oxygen concentrations (Bohrmann et al., 2008).

Fig. 2. Seafloor photographs of carbonate deposits on the Makran slope. (A) Recovery of authigenic carbonate from beneath orange and white microbial mats within the oxygen minimum zone (OMZ) by means of the ROV manipulator arm (sample GeoB12353-7, location Flare site 15); note the domal shape of the carbonate deposit (left) and the black sediment underneath the mat (right); (B) extensive patches of white and orange microbial 
mats cover the seafloor at Flare site 2, located at the lower OMZ boundary; note the abundant small polychaetes (black arrows) at the margin of the white mat; insert photo in the lower left shows recovery of sample GeoB12315-3; (C) colony of bathymodiolin mussels attached to an extensive carbonate deposit at Flare site 11; white arrows point to white galatheid crabs strolling among the bivalves; (D) carbonate crust outcrop with single tubeworm colony at Flare site 7 (inactive site); (E) abundant bathymodiolin mussels, white sponges (lower right), as well as deep-sea barnacles (insert lower left), settling on authigenic carbonate (Flare site 7, active site); arrows point out small galatheid crabs among bathymodiolin mussles; (F) outcrop of a carbonate crust at location Flare site 6; note the tubeworm colony, scattered white sponges (above tube worms), and bathymodiolin mussels attached to the carbonate surface.

Fig. 3. Fabrics of sampled carbonates; Ara = aragonite; $\mathrm{Mg}-\mathrm{Cc}=$ magnesian calcite; $\mathrm{GeoB}=$ Faculty of Geosciences, University of Bremen; OMZ = oxygen minimum zone. (A) Coarsely laminated, highly porous sample, showing alternating friable dark grey and indurated light brownish wavy laminae (dashed line); note various size and geometry of pores (arrows); (B) platy homogeneous limestone sample; the dark grey stain of the margin stems from resin embedment; (C) porous intraformational breccia of cemented sediment clasts; note the thin rims of white isopachous cement and large pores; articulated bivalves are encaged within large pores (arrows); (D) breccia of cemented mudclasts and abundant bivalve shell fragments; note the overall chaotic fabric and two articulated bivalves in the lower left (arrows); (E) cemented background sediment with a cm-thick cement crust; (F) intraformational breccia of angular to sub-rounded Mg-calcite cemented sediment clasts; pore space between clasts is largely filled by cement and/or semi-lithified late sediment infill; note variable clast geometry and fewer bivalve shell fragments compared to (D). 
Fig. 4. Petrography of the Makran carbonates. (A) Clear isopachous aragonite enclosing dark clotted aggregates; isopachous growth of clear cement created slightly curved polygonal boundaries (sample GeoB12353-7); (B) clotted and isopachous fibrous aragonite (GeoB12353-7) under polarized light (left, crossed nicols) and under UV light radiation (right); note the difference between the non-luminescent clear aragonite and bright luminescent clotted aragonite; (C) microcrystalline aragonite-cemented sediment (GeoB12315-3); note silt-sized quartz grains and opaque pyrite (crossed nicols); (D) aragonite-cemented sediment clasts re-cemented by isopachous fibrous aragonite (GeoB12348-1); note the two planktic foraminiferal tests enclosed by fibrous aragonite (centre, right); (E) Mg-calcite cemented sediment clast (upper right), bivalve shell fragments (left), and abundant peloids (bottom and central right) cemented by isopachous fibrous cement; note sediment clast with quartz grains (GeoB12338-13); (F) sediment fracture filled with fibrous aragonite and late semi-lithified sediment infill (upper centre); black (GeoB12324-2, crossed nicols; pore space appears black).

Fig. 5. Carbon and oxygen stable isotope compositions (\%o) of the Makran cold-seep carbonates; filled symbols indicate oxygen minimum zone samples.

Fig. 6. Relative percentages of archaeal (isoprenoids) and bacterial (hopanoids, DAGEs, MAGEs, fatty acids) lipid biomarkers in the carbonate samples; DAGEs = dialkyl glycerol diethers; MAGEs = mono alkyl glycerol monoethers; OMZ = oxygen minimum zone.

Fig. 7: Partial HPLC-APCI-MS chromatograms (base peaks) of the acetylated DCM fraction; $\mathrm{OMZ}=$ oxygen minimum zone. Base peaks: aminotetrol (black): $m / z$ 772; aminotriol (dark grey): $m / z, 714$; bacteriohopanetetrol (light grey): $m / z 655$. 
Figure 1
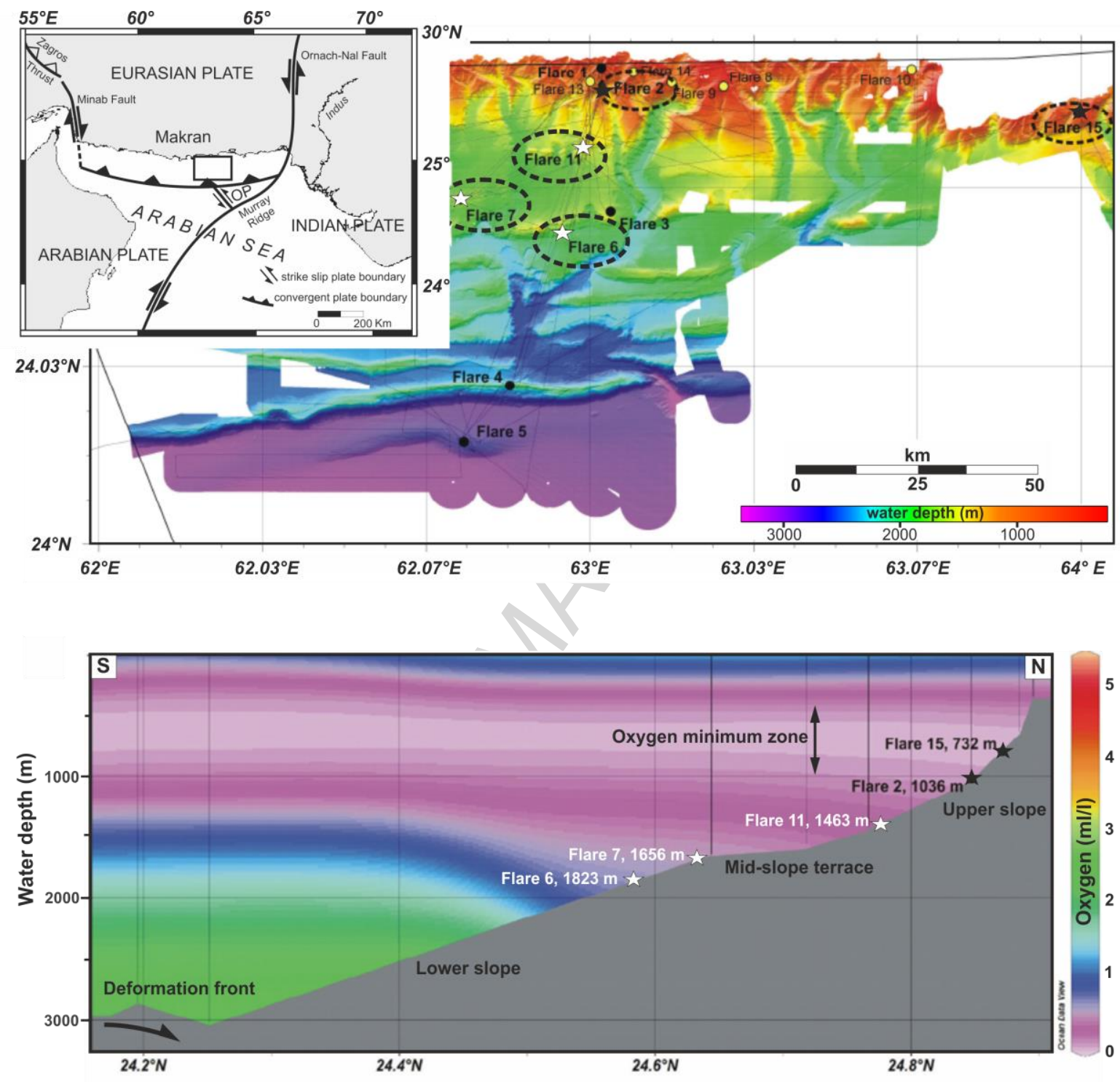
Figure 2
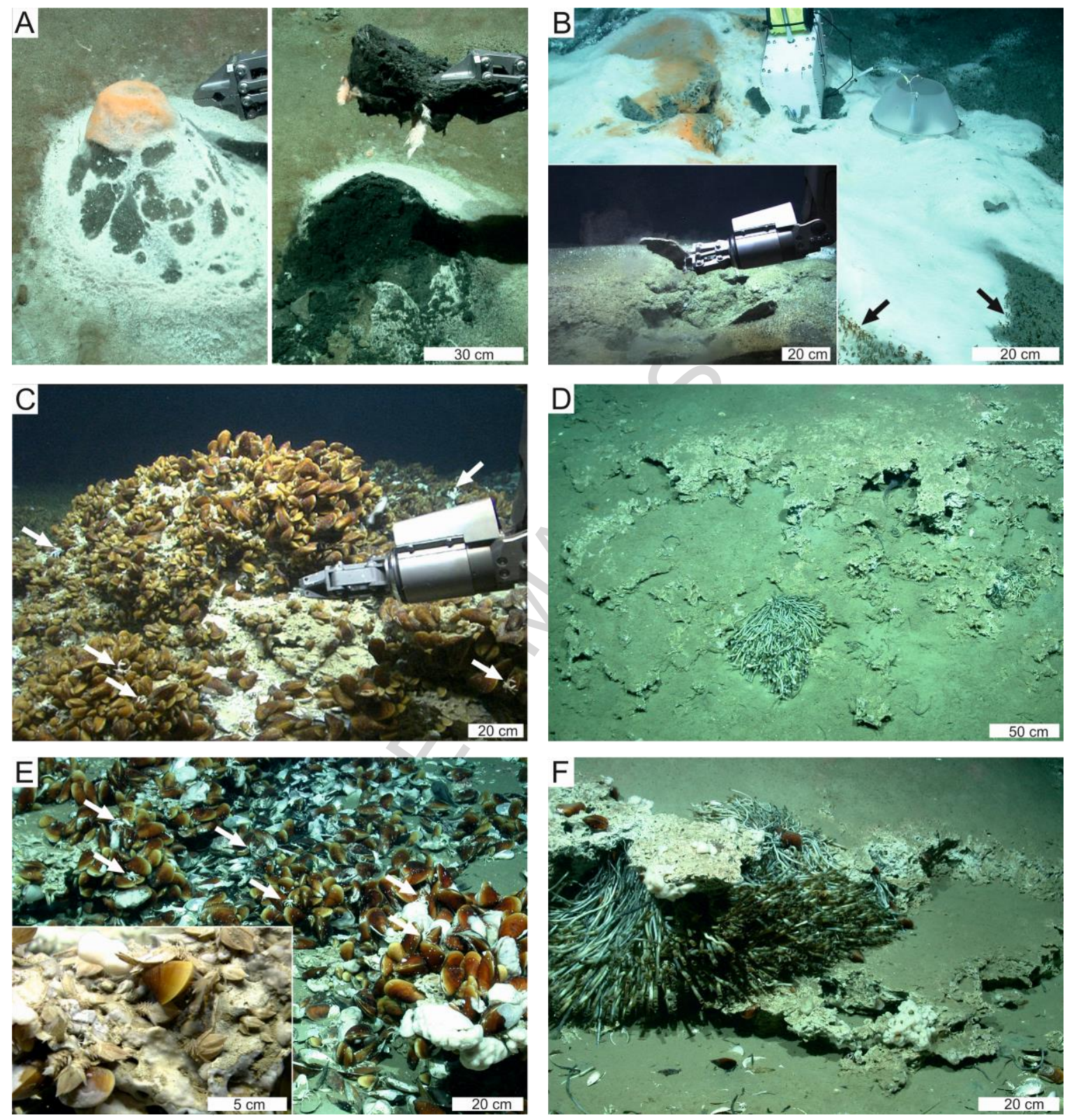
Figure 3
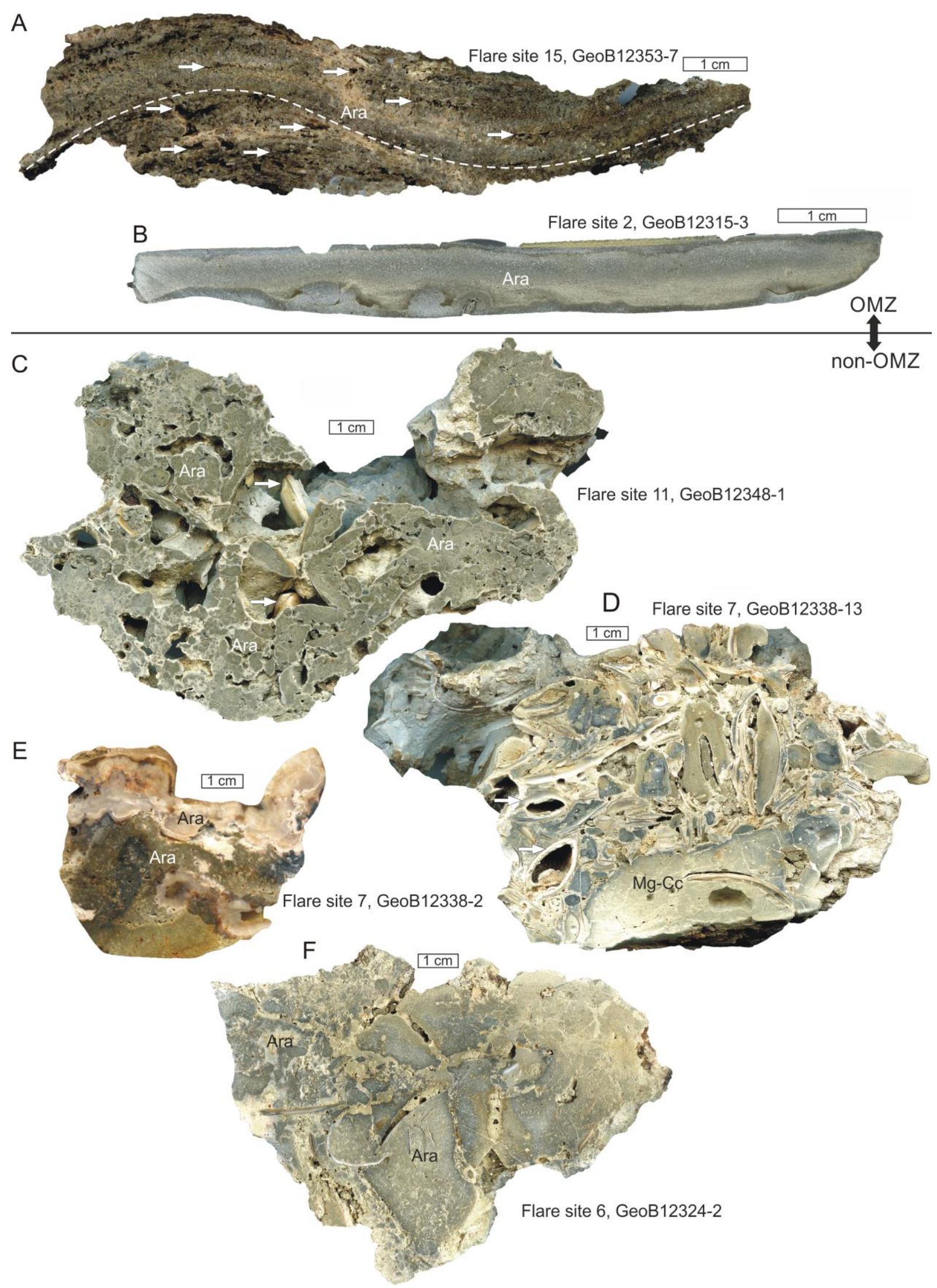
Figure 4
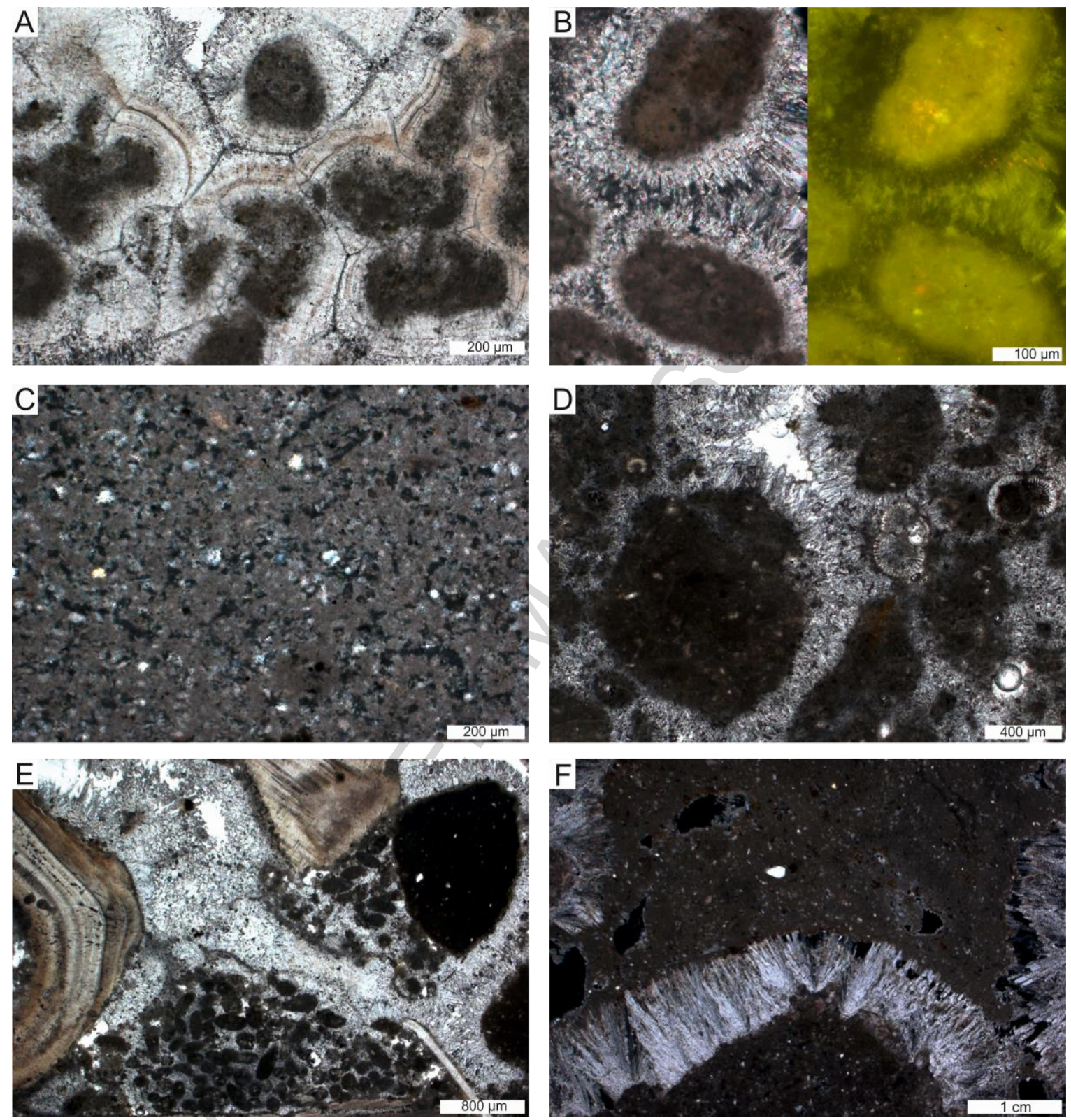
Figure 5

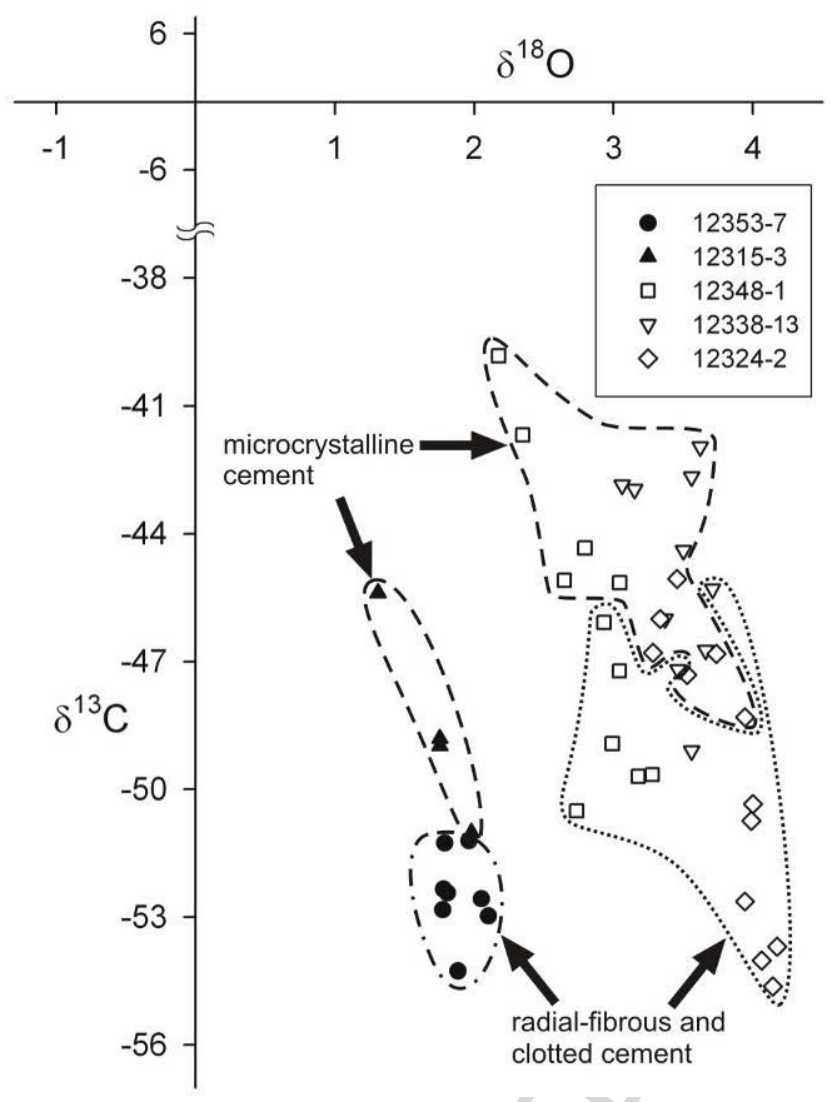


Figure 6

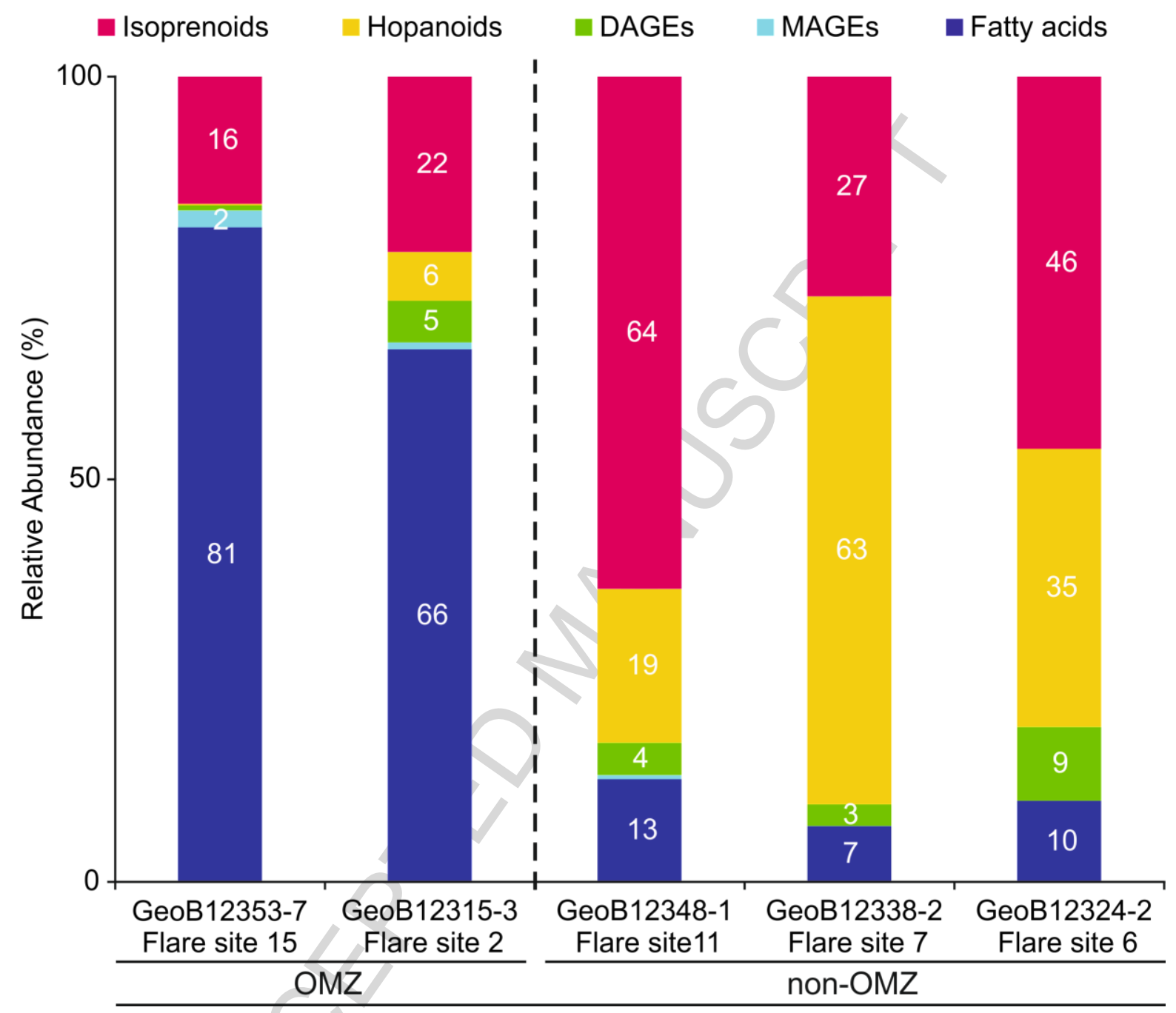


Figure 7

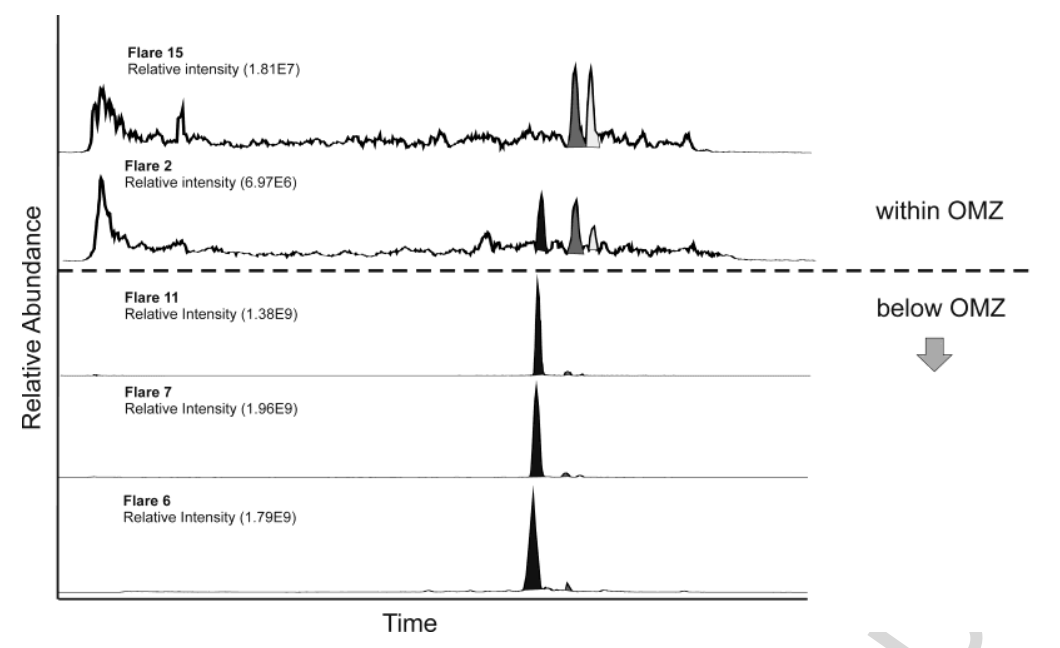


Table 1

\begin{tabular}{|c|c|c|c|c|c|c|}
\hline Location & $\begin{array}{l}\text { Sample code } \\
\quad(\text { GeoB })\end{array}$ & $\begin{array}{l}\text { Water } \\
\text { depth } \\
(\mathrm{m})\end{array}$ & $\begin{array}{l}\text { Latitude } \\
\qquad[\mathrm{N}]\end{array}$ & $\begin{array}{l}\text { Longitude } \\
\quad[\mathrm{E}]\end{array}$ & Seafloor observations & References \\
\hline \multicolumn{7}{|l|}{$\mathrm{OMZ}$} \\
\hline $\begin{array}{l}\text { Flare } \\
\text { site } 15\end{array}$ & $\begin{array}{c}\text { GeoB12353- } \\
7\end{array}$ & 731 & $24^{\circ} 48.46^{\prime}$ & $63^{\circ} 59.65^{\prime}$ & $\begin{array}{l}\text { Microbial mats; rising gas } \\
\text { bubbles; authigenic carbonate }\end{array}$ & $\begin{array}{l}\text { Bohrmann } \\
\text { et al., }\end{array}$ \\
\hline $\begin{array}{l}\text { Flare } \\
\text { site } 2\end{array}$ & $\begin{array}{l}\text { GeoB12315- } \\
3\end{array}$ & 1025 & $24^{\circ} 50.78^{\prime}$ & $63^{\circ} 01.42$ & $\begin{array}{l}\text { Widespread filamentous microbial } \\
\text { mats; vigorous gas bubble } \\
\text { emissions; metazoans } \\
\text { (polychaetes, vesicomyid clams); } \\
\text { broken carbonate slabs at }\end{array}$ & $\begin{array}{l}\text { Bohrmann } \\
\text { et al., } \\
2008 \text {; } \\
\text { Fischer et } \\
\text { al.. 2012: }\end{array}$ \\
\hline \multicolumn{7}{|l|}{$\begin{array}{l}\text { non- } \\
\text { OMZ }\end{array}$} \\
\hline $\begin{array}{l}\text { Flare } \\
\text { site } 11\end{array}$ & $\begin{array}{c}\text { GeoB12348- } \\
1\end{array}$ & 1475 & & $2^{\circ} 58.63$ & $\begin{array}{l}\text { Carbonate crust; abundant } \\
\text { bathymodiolin mussels and } \\
\text { oaletheid crahs } \cdot \text { oas hulhhle }\end{array}$ & $\begin{array}{l}\text { Bohrmann } \\
\text { et al., } \\
\text { ?nns. }\end{array}$ \\
\hline $\begin{array}{l}\text { Flare } \\
\text { site } 7\end{array}$ & $\begin{array}{l}\text { GeoB } 12338- \\
2, \\
\text { GeoB } 12338-\end{array}$ & 1656 & & $62^{\circ} 44.29^{\prime}$ & $\begin{array}{l}\text { Extensive carbonate crust; } \\
\text { abundant bathymodiolin mussels, } \\
\text { sponges, deep-sea barnacles, } \\
\text { Extensive carbonate crust; }\end{array}$ & $\begin{array}{l}\text { Bohrmann } \\
\text { et al., } \\
2008 \text {; }\end{array}$ \\
\hline $\begin{array}{l}\text { Flare } \\
\text { site } 6\end{array}$ & $\begin{array}{c}\text { GeoB12324- } \\
2\end{array}$ & 1823 & & $62^{\circ} 56.32^{\prime}$ & $\begin{array}{l}\text { abundant bathymodiolin mussels } \\
\text { and vesicomyid clams, tube } \\
\text { worms, and sponges: no gas }\end{array}$ & $\begin{array}{l}\text { et al., } \\
2008 \text {; } \\
\text { Römer et }\end{array}$ \\
\hline
\end{tabular}


Table 2

\begin{tabular}{ccccccccc}
\hline & & & $\mathrm{T}$ & \multicolumn{3}{c}{$\mathrm{CaC}$} & & \\
Sample & Fla & Dive & $\left({ }^{\circ}\right.$ & & $\mathrm{O}_{3}$ & Major & Minor & Trace \\
$($ GeoB) & re & numb & C) & Fabric & $($ wt- & & \\
& site & er & B & & $\%)$ & & \\
& & & W & & $\%$ & & \\
\hline
\end{tabular}

\section{OMZ}

\begin{tabular}{|c|c|c|c|c|c|c|c|c|}
\hline $\begin{array}{c}12353- \\
7\end{array}$ & 15 & 196 & $\begin{array}{c}10 . \\
7\end{array}$ & $\begin{array}{c}\text { Stromatoliti } \\
\text { c }\end{array}$ & 99 & $\Delta$ & Mic & $\mathrm{Qz}, \mathrm{Cc}$ \\
\hline $\begin{array}{c}12315- \\
3\end{array}$ & 2 & 181 & 8.5 & $\begin{array}{l}\text { Homogenou } \\
\text { s mudstone }\end{array}$ & 65 & & $\begin{array}{l}\text { Fsp, Mic, } \\
\text { Chl }\end{array}$ & Cc, Dol \\
\hline \multicolumn{9}{|l|}{$\begin{array}{l}\text { non- } \\
\text { OMZ }\end{array}$} \\
\hline $\begin{array}{c}12348- \\
1\end{array}$ & 11 & 194 & 5.3 & $\begin{array}{l}\text { Intraformati } \\
\text { onal breccia }\end{array}$ & & Ara & $\begin{array}{l}\text { Mic, Qz, } \\
\text { Fsp }\end{array}$ & Chl, Cc \\
\hline $\begin{array}{l}(*) 123 \\
38-2\end{array}$ & 7 & 191 & 4.4 & $\begin{array}{l}\text { Homogeneo } \\
\text { us mudstone }\end{array}$ & 81 & Ara & Cc, Dol & $\begin{array}{c}\text { Qz, Mic, Chl, } \\
\text { Fsp }\end{array}$ \\
\hline $\begin{array}{c}12338- \\
13\end{array}$ & 7 & 191 & 4.4 & $\begin{array}{l}\text { Intraformati } \\
\text { onal breccia }\end{array}$ & n.a. & $\begin{array}{c}(* *) \mathrm{Mg}-\mathrm{Cc}, \\
\text { Mic, Chl }\end{array}$ & $\begin{array}{l}(* *) \mathrm{Cc}, \\
\text { Ara, Qz }\end{array}$ & $(* *) \mathrm{Fsp}$ \\
\hline $\begin{array}{c}12324- \\
2\end{array}$ & 6 & 186 & 3.6 & $\begin{array}{l}\text { Intraformati } \\
\text { onal breccia }\end{array}$ & 80 & Ara & $\begin{array}{c}\text { Mic, Fsp, } \\
\text { Qz }\end{array}$ & $\mathrm{Cc}, \mathrm{Chl}$ \\
\hline
\end{tabular}

(*) adopted from Himmler et al., 2010; (**) No bulk-rock data, only the matrix of a sediment clast was analysed. 
Table 3

\begin{tabular}{|c|c|c|c|c|c|c|c|c|c|c|c|}
\hline $\begin{array}{l}\text { Samp } \\
\text { le } \\
(\mathrm{Geo} \\
\mathrm{B})\end{array}$ & $\begin{array}{l}\text { Litholo } \\
\text { gy }\end{array}$ & $\begin{array}{c}\text { Weig } \\
\text { ht } \\
(\mathrm{mg})\end{array}$ & $\begin{array}{l}{ }^{238} \mathrm{U} \\
(\mu \mathrm{g} / \\
\mathrm{g}) \pm \\
2 \sigma\end{array}$ & $\begin{array}{c}{ }^{232} \mathrm{~T} \\
\mathrm{~h} \\
(\mathrm{ng} / \\
\mathrm{g}) \pm \\
2 \sigma\end{array}$ & $\begin{array}{c}{ }^{230} \mathrm{~T} \\
\mathrm{~h} \\
(\mathrm{pg} / \\
\mathrm{g}) \pm \\
2 \sigma\end{array}$ & $\begin{array}{l}{ }^{230} \mathrm{Th} /{ }^{232} \\
\mathrm{Th}) \pm 2 \sigma\end{array}$ & $\begin{array}{l}\left({ }^{238} \mathrm{U} /{ }^{232}\right. \\
\mathrm{Th}) \pm 2 \sigma\end{array}$ & $\begin{array}{l}\left({ }^{232} \mathrm{Th} /{ }^{23}\right. \\
\left.{ }^{8} \mathrm{U}\right) \pm 2 \sigma\end{array}$ & $\begin{array}{l}{ }^{230} \mathrm{Th} /{ }^{238} \\
\mathrm{U}) \pm 2 \sigma\end{array}$ & $\begin{array}{l}\delta^{234} U \\
i \pm 2 \sigma\end{array}$ & $\begin{array}{c}\text { Age } \\
(\mathrm{ka}) \pm \\
2 \sigma\end{array}$ \\
\hline \multicolumn{12}{|l|}{ OMZ } \\
\hline $\begin{array}{c}1231 \\
5-3\end{array}$ & $\begin{array}{l}\text { Bulk } \\
\text { rock }\end{array}$ & 14.9 & $\begin{array}{c}2.23 \\
5 \pm \\
0.00 \\
4\end{array}$ & $\begin{array}{c}464 \\
6 \pm \\
11\end{array}$ & $\begin{array}{l}17 . \\
8 \pm \\
0.1\end{array}$ & $\begin{array}{c}0.71 \pm \\
0.01\end{array}$ & $\begin{array}{c}1.470 \pm \\
0.004\end{array}$ & $\begin{array}{c}0.681 \pm \\
0.002\end{array}$ & $\begin{array}{c}0.485 \pm \\
0.004\end{array}$ & $\begin{array}{l}82 . \\
8 \pm \\
2.8\end{array}$ & $\begin{array}{l}0.0 \\
1 \pm \\
32\end{array}$ \\
\hline \multicolumn{12}{|l|}{$\begin{array}{l}\text { non- } \\
\text { OMZ }\end{array}$} \\
\hline $\begin{array}{c}1234 \\
8-1\end{array}$ & $\begin{array}{l}\text { Bulk } \\
\text { rock }\end{array}$ & 11.4 & $\begin{array}{c}5.88 \\
\pm \\
0.01\end{array}$ & $\begin{array}{c}193 \\
0 \pm \\
6\end{array}$ & $\begin{array}{l}37 . \\
2 \pm \\
0.2\end{array}$ & 0.01 & $\begin{array}{c}9.31 \pm \\
0.03\end{array}$ & $\begin{array}{c}0.10737 \pm \\
0.00039\end{array}$ & $\begin{array}{c}0.100 \pm \\
0.001\end{array}$ & $\begin{array}{l}123 \\
.2 \pm \\
1.5\end{array}$ & $\begin{array}{c}2.3 \\
\pm \\
3.9\end{array}$ \\
\hline $\begin{array}{c}1233 \\
8-2\end{array}$ & $\begin{array}{c}\text { Cemen } \\
\mathrm{t}\end{array}$ & 14.4 & $\begin{array}{c}5.64 \\
\pm \\
0.01\end{array}$ & $\begin{array}{l}18.4 \\
0 \pm \\
0.04\end{array}$ & 0.1 & $\begin{array}{c}142.8 \pm \\
1.3\end{array}$ & $936 \pm 3$ & $\begin{array}{c}0.00107 \pm \\
0.000003 \\
2\end{array}$ & $\begin{array}{c}0.152 \pm \\
0.001\end{array}$ & $\begin{array}{l}142 \\
.2 \pm \\
0.9\end{array}$ & $\begin{array}{l}15 . \\
5 \pm \\
0.2\end{array}$ \\
\hline $\begin{array}{l}1233 \\
8-13\end{array}$ & $\begin{array}{l}\text { Bulk } \\
\text { rock }\end{array}$ & 12.3 & 7.93 & $\begin{array}{c}455 \\
3 \pm \\
9\end{array}$ & $\begin{array}{l}14 . \\
1 \pm \\
0.1\end{array}$ & $\begin{array}{c}1.53 \pm \\
0.01\end{array}$ & $\begin{array}{c}5.32 \pm \\
0.02\end{array}$ & $\begin{array}{c}0.18801 \pm \\
0.00054\end{array}$ & $\begin{array}{c}0.287 \pm \\
0.001\end{array}$ & $\begin{array}{l}141 \\
.3 \pm \\
2.1\end{array}$ & $\begin{array}{r}16 \\
\pm 8\end{array}$ \\
\hline $\begin{array}{c}1232 \\
4-2\end{array}$ & $\begin{array}{l}\text { Bulk } \\
\text { rock }\end{array}$ & 11.9 & $\begin{array}{c}7.73 \\
\pm \\
0.02\end{array}$ & $\begin{array}{c}279 \\
7 \pm \\
8\end{array}$ & $\begin{array}{l}34 . \\
7 \pm \\
0.1\end{array}$ & $\begin{array}{c}2.32 \pm \\
0.01\end{array}$ & $\begin{array}{c}8.44 \pm \\
0.03\end{array}$ & $\begin{array}{c}0.11844 \pm \\
0.00040\end{array}$ & $\begin{array}{c}0.274 \pm \\
0.001\end{array}$ & $\begin{array}{l}137 \\
.0 \pm \\
2.6\end{array}$ & $\begin{array}{l}19 . \\
8 \pm \\
5.0\end{array}$ \\
\hline
\end{tabular}


Table 4

\begin{tabular}{|c|c|c|c|c|c|c|c|c|c|c|}
\hline Location & $\mathrm{OMZ}$ & & & & non-ON & & 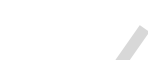 & & & \\
\hline $\begin{array}{l}\text { GeoB } \\
\text { sample } \\
\text { (Flare site) }\end{array}$ & $\begin{array}{l}12353- \\
7 \text { (Flare } \\
\text { site } 15)\end{array}$ & & $\begin{array}{l}12315- \\
3 \text { (Flare } \\
\text { site 2) }\end{array}$ & & $\begin{array}{l}12348- \\
1 \text { (Flare } \\
\text { site 11) }\end{array}$ & & $\begin{array}{l}12338- \\
2 \\
\text { (Flare } \\
\text { site } 7 \text { ) }\end{array}$ & & $\begin{array}{l}12324- \\
2 \text { (Flare } \\
\text { site 6) }\end{array}$ & \\
\hline & $\begin{array}{l}\text { Conten } \\
\text { ts }(\mu \mathrm{g} / \mathrm{g} \\
\text { rock })\end{array}$ & $\begin{array}{l}\delta^{13} \mathrm{C} \\
(\% 0)\end{array}$ & $\begin{array}{l}\text { Conten } \\
\text { ts }(\mu \mathrm{g} / \mathrm{g} \\
\text { rock) }\end{array}$ & $\begin{array}{l}\delta^{13} \mathrm{C} \\
(\% \circ)\end{array}$ & $\begin{array}{l}\text { Conten } \\
\text { ts }(\mu \mathrm{g} / \mathrm{g} \\
\text { rock) }\end{array}$ & $\begin{array}{l}\delta^{13} \mathrm{C} \\
(\% 0)\end{array}$ & $\begin{array}{l}\text { Content } \\
\mathrm{s}(\mu \mathrm{g} / \mathrm{g} \\
\text { rock })\end{array}$ & $\begin{array}{l}\delta^{13} \mathrm{C} \\
(\% \circ)\end{array}$ & $\begin{array}{l}\text { Conten } \\
\text { ts }(\mu \mathrm{g} / \mathrm{g} \\
\text { rock) }\end{array}$ & $\begin{array}{l}\delta^{13} \mathrm{C} \\
(\% 0)\end{array}$ \\
\hline $\begin{array}{l}\text { Archaeal } \\
\text { biomarker } \\
\text { s }\end{array}$ & & & & & & & & & & \\
\hline Crocetane & 376 & -127 & 205 & -85 & 481 & -78 & 112 & -122 & 17 & -118 \\
\hline $\begin{array}{l}\text { PMI \& } \\
\text { unsat. } \\
\text { PMI }\end{array}$ & 528 & $\begin{array}{l}-125 \\
\#\end{array}$ & 198 & ${ }^{-106}$ & 672 & $\begin{array}{l}-121 \\
\#\end{array}$ & 47 & -121 & 43 & -125 \\
\hline Archaeol & 780 & -123 & 200 & -118 & 870 & -115 & 64 & -121 & 579 & -120 \\
\hline $\begin{array}{l}\text { sn2-OH- } \\
\mathrm{Ar}\end{array}$ & 2271 & -120 & & & 1827 & -115 & 132 & -117 & 843 & -120 \\
\hline $\begin{array}{l}\text { sn3-OH- } \\
\mathrm{Ar}\end{array}$ & 25 & & tr. & n.m. & 47 & n.m. & 5 & -114 & tr. & n.m. \\
\hline $\begin{array}{l}\text { sn2-OH- } \\
\mathrm{Ar} / \mathrm{Ar}\end{array}$ & 2.9 & & & & 2.1 & & 2.1 & & 1.5 & \\
\hline
\end{tabular}

Bacterial biomarker $\mathrm{s}$

(aliphatic compound s)

\begin{tabular}{lllllllllll}
\hline$i-\mathrm{C}_{15: 0}$ & 7224 & -107 & 321 & -86 & 174 & -94 & 21 & -97 & 98 & -88 \\
$a i-\mathrm{C}_{15: 0}$ & 5433 & -101 & 1324 & -104 & 321 & -96 & 60 & -97 & 125 & -85 \\
$\mathrm{C}_{16: 1 \omega 5 \mathrm{c}}$ & 4703 & -98 & 359 & -89 & 267 & -94 & 15 & -95 & 100 & -88 \\
$\mathrm{C}_{17: 1 \omega 6}$ & 1725 & -98 & n.d. & n.m. & 20 & n.m. & n.d. & n.m. & n.d. & n.m. \\
$c y \mathrm{C}_{17: 0 \omega 5,6}$ & 1415 & -112 & 35 & n.m. & 44 & -102 & n.d. & n.m. & n.d. & n.m. \\
MAGE & 326 & -98 & 7 & n.m. & 24 & n.m. & n.d. & n.m. & n.d. & n.m. \\
$\mathrm{C}_{16: 1 \omega 7 c}$ & & & & & & & & & & \\
MAGE & 196 & -98 & 19 & n.m. & 8 & n.m. & n.d. & n.m. & n.d. & n.m. \\
$\mathrm{C}_{16: 1 \omega 5 \mathrm{c}}$ & & & & & & & & & &
\end{tabular}




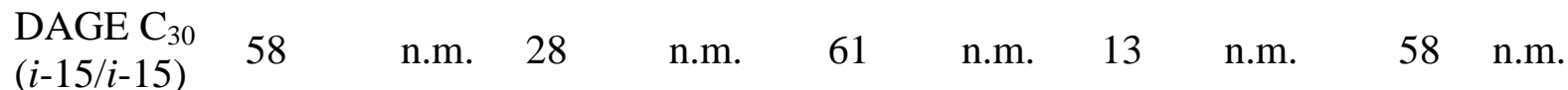
DAGE $\mathrm{C}_{30}$

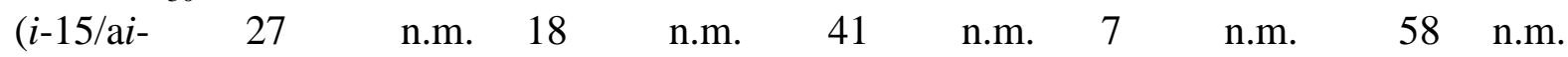
$15)$

DAGE $\mathrm{C}_{30}$ (ai-15/ai$\begin{array}{llllllllll}82 & -93 & 113 & -106 & 158 & \text { n.m. } & 17 & -105 & 179 & -107\end{array}$ 15) aili- $\mathrm{C}_{15}$ fatty acid $4.1+1.9$ 2.8 1.3 
Table 5

\begin{tabular}{|c|c|c|c|c|c|c|c|c|c|c|}
\hline Location & \multicolumn{4}{|l|}{ OMZ } & \multicolumn{6}{|c|}{ non-OMZ } \\
\hline \multirow[t]{2}{*}{$\begin{array}{l}\text { GeoB } \\
\text { sample } \\
\text { (Flare site) }\end{array}$} & \multicolumn{2}{|l|}{$\begin{array}{l}12353-7 \\
\text { (Flare } \\
\text { site } 15)\end{array}$} & \multicolumn{2}{|l|}{$\begin{array}{l}\text { 12315-3 } \\
\text { (Flare } \\
\text { site 2) }\end{array}$} & \multicolumn{2}{|l|}{$\begin{array}{l}12348-1 \\
\text { (Flare } \\
\text { site } 11 \text { ) }\end{array}$} & \multicolumn{2}{|l|}{$\begin{array}{l}12338-2 \\
\text { (Flare } \\
\text { site } 7 \text { ) }\end{array}$} & \multicolumn{2}{|l|}{$\begin{array}{l}12324 \\
-2 \\
\text { (Flare } \\
\text { site } 6 \text { ) }\end{array}$} \\
\hline & $\begin{array}{l}\text { Content } \\
\mathrm{s} \\
(\mu \mathrm{g} / \mathrm{g} \\
\text { rock })\end{array}$ & $\begin{array}{l}\delta^{13} \\
\mathrm{C} \\
(\%)\end{array}$ & $\begin{array}{l}\text { Content } \\
\text { s }(\mu \mathrm{g} / \mathrm{g} \\
\text { rock })\end{array}$ & $\begin{array}{l}\delta^{13} \\
\mathrm{C} \\
(\%)\end{array}$ & $\begin{array}{l}\text { Content } \\
\mathrm{s} \\
(\mu \mathrm{g} / \mathrm{g} \\
\text { rock })\end{array}$ & $\begin{array}{l}\delta^{13} \\
\mathrm{C} \\
(\%)\end{array}$ & $\begin{array}{l}\text { Content } \\
\mathrm{s}(\mu \mathrm{g} / \mathrm{g} \\
\mathrm{rock})\end{array}$ & $\begin{array}{l}\delta^{13} \\
\mathrm{C} \\
(\%)\end{array}$ & $\begin{array}{l}\text { Content } \\
(\mu \mathrm{g} / \mathrm{g} \\
\text { rock })\end{array}$ & $\begin{array}{l}\delta^{13} \mathrm{C} \\
(\%)\end{array}$ \\
\hline $\begin{array}{l}17 \beta(\mathrm{H}), \\
21 \beta(\mathrm{H})-32- \\
\text { hopanol } \\
17 \beta(\mathrm{H}), \\
21 \beta(\mathrm{H})-32- \\
\text { hopanoic } \\
\text { acid }\end{array}$ & n.d. & -48 & 187 & -41 & 1052 & -84 & 487 & -81 & 610 & -80 \\
\hline Diplopterol & n.d. & n.m. & n.d. & n.m. & 82 & -70 & 66 & n.m. & 36 & n.m \\
\hline Aminotriol & ++ & n.m. & + & n.m. & n.m. & n.m. & $\operatorname{tr}$ & n.m. & tr. & n.m \\
\hline $\begin{array}{l}\text { Aminotetro } \\
1\end{array}$ & n.d. & n.m. & & tr. & ++ & -78 & ++ & -73 & ++ & -75 \\
\hline
\end{tabular}




\section{Table 6}

\begin{tabular}{lccccc}
\hline & Flare site 15 (OMZ) & Flare site 2 (OMZ) & Flare site 11 & Flare site 7 & Flare site 6 \\
\hline$\delta^{13} \mathrm{C}_{\text {methane }}$ & -70 & $-69 *$ & n.a. & -67 & n.a. \\
$\delta^{13} \mathrm{C}_{\text {carbonate (av.) }}$ & -53 & -49 & -46 & -46 & -50 \\
\hline$\delta^{13} \mathrm{C}_{\text {lipid biomarkers }}$ & & & & & \\
\cline { 1 - 1 } & -124 & -107 & -107 & -119 & -121 \\
$\mathrm{SRB}$ (av.) & -101 & -99 & -97 & -99 & -92 \\
$\mathrm{MOX}$ (av.) & n.a. & n.a. & -77 & -76 & -78 \\
\hline$\Delta \delta^{13} \mathrm{C}_{\text {methane-carbonate }}$ & -17 & -20 & n.c. & -22 & n.c. \\
$\Delta \delta^{13} \mathrm{C}_{\text {ANME-methane }}$ & -54 & -38 & n.c. & -52 & n.c. \\
$\Delta \delta^{13} \mathrm{C}_{\mathrm{MOX} \text {-methane }}$ & n.a. & n.a. & n.c. & -9 & n.c. \\
\hline
\end{tabular}

